NBER WORKING PAPER SERIES

\title{
THE RELATIVE STABILITY OF MONEY AND CREDIT "VELOCITIES" IN THE UNITED STATES: EVIDENCE AND SOME SPECULATIONS
}

Ben jamin M. Friedman

Working Paper No. 645

NATIONAL BUREAU OF ECONOMIC RESEARCH 1050 Massachusetts Avenue

Cambridge MA 02138

March 1981

The research reported here is part of the NBER's research program in Financial Markets and Monetary Economics and project on the Changing Role of Debt and Equity Finances in the United States, which is being financed by a grant from the American Council of Life Insurance. Any opinions expressed are those of the author and not those of the National Bureau of Economic Research. 
The Relative Stability of Money and Credit "Velocities" in the United States:

Evidence and Some Speculations

\section{ABSTRACT}

Is credit as closely related to income as is money? Results presented in the first half of this paper, based on a variety of methodological approaches, consistently indicate that the aggregate of outstanding credit liabilities of all nonfinancial borrowers in the United States bears as close a relationship to U.S. nonfinancial activity as do the more familiar asset aggregates like the money stock (however measured) or the monetary base. In contrast to the asset aggregates, however, which exhibit little overall difference among themselves in this context, total nonfinancial indebtedness appears to be unique among credit aggregates in bearing this close relationship to income. Moreover, additional evidence of offsetting movements of the public and private components of total nonfinancial indebtedness further substantiates the case for stability in the aggregate.

The second half of the paper suggests three hypotheses that provide internally consistent potential explanations for this phenomenon: (1) an "ultrarationality" hypothesis which emphasizes acute perceptions and offsetting actions on the part of the private sector, (2) a "capital leveraging" hypothesis which emphasizes borrowing limitations and the need for tangible collateral, and (3) an "asset demand" hypothesis which emphasizes the private sector's role as a net lender. Initial efforts to match these hypotheses against data for the U.S. household and corporate business sectors yield only mixed results, however. The stability of the credit-to-income relationship remains for the present a major puzzle, therefore, although these three hypotheses do look sufficiently promising to warrant a much closer investigation. 


\section{EVIDENCE AND SOME SPECUIAATIONS}

Benjamin M. Friedman*

Harvard University

It is curious that economic analysis has traditionally placed so much more emphasis on money than on credit.

In the simplest abstraction to an economy with no privately issued financial instruments, there is no such thing as credit, and money exists only in the form of government-issued base money. The relevance of such an abstraction is questionable, however, in a context in which there exist not only privately issued financial instruments but also a large quantity and rich variety of institutions whose business consists almost exclusively of issuing and holding such instruments. In an actual economy like that of the United States, most money is in fact not base money but bank money, and privately issued financial instruments constitute the great majority of all financial instruments held. Of course it is always possible to proceed on the assumption that privately issued financial instruments exist but do not matter much, so that the economy's privately issued liabilities simply offset the remainder of its financial assets, and base money is once again all that matters for economic activity beyond some level of disaggregated detail. Although there have been some proponents of such a view, ${ }^{l}$ it is nonetheless inconsistent with the emphasis more typically placed on bank money as well as base money in most analysis.

Once the analysis moves beyond an exclusive focus on base money, however - thereby acknowledging that financial intermediation not only 
exists but also matters - economic theory provides no a priori reason whatever to suspect a role for the nonbank public's money holdings but not its credit liabilities. For given growth in base money, the behavior of the banking system as well as of the nonbank public determines the growth of both bank money and bank credit, and does so jointly with the determination of the growth of nonbank financial instruments and of nonfinancial economic activity. In theoretical analysis there is no justification for paying attention to the "money" side of this process while disregarding the "credit" side. In applied analysis the most familiar argument for emphasizing money while disregarding credit usually rests on some kind of implicit empirical judgment that, especially for the United States, the arbitrariness associated with defining "credit" measures is significantly more troublesome than the arbitrariness associated with defining "money" measures. In a standard example, whether a particular credit extension goes through the banking system or the commercial paper market (or even the long-term bond market) is presumably at most a second-order matter. Recent developments have done much to vitiate this familiar empirical judgment, however, and there now exist substantial and rapidly growing anomalies on the "money" side that are fully comparable to those that have long been familiar on the "credit" side. Surely it is also a second-order matter whether the public holds bank-issued money market certificates (enabling banks to make direct loans), in which case "money" increases, or holds commercial paper via money market fund shares that may be checkable but are excluded from "money" nonetheless. More broadly, the conventional inclusion in "money" of non-deposit claims against depositissuing institutions (for example, seven-year saving certificates) contrasts oddly with the exclusion of fully liquid claims against everyone else. This paper's point of departure is the simple observation that, in 
the United States during the post World war II period, the total amount of debt claims issued in the credit markets by all nonfinancial participants in the economy has born a remarkably stable relationship to nonfinancial economic activity as measured by gross national product - arguably, a more stable relationship than that shown by the monetary base or by any of the familiar "M" measures that include bank money. This observed stability of the economy's aggregate nonfinancial debt ratio, taken by itself, is not necessarily surprising. What makes it surprising, however, is that the economy-wide total has been so stable despite wide variation in the debt issuing activity of the different sectors of whose claims the total consists. In particular, households and nonfinancial corporations have paced their issuance of debt, in both the secular and the cyclical time frames, so as almost exactly to offset the secular decline and cyclical variation in the indebtedness of the federal government.

The paper's object is to make a beginning (for it is only that) toward understanding the role that debt plays in the economic system and hence the behavior underlying the observed stability of the debt-to-income relationship in the United States. This line of research appears, at least at the outset, to be of potential value in several regards in addition to the light it may shed on more basic questions of economic behavior. For example, some of the hypotheses that may possibly explain the existence of a stable debt ratio have fairly direct implications for whether fiscal policy either can provide an effective economic stimulus or will merely "crowd out" private activity. Similarly, some of these hypotheses bear implications for leverage structures, in the sense of the mix of debt and equity by which individuals and businesses in the private economy will finance their asset holdings. The results of such research also have potential implications for the choice of target 
variables for monetary policy, especially under the currently prevalent approach that employs some endogenous variable (like money) as an intermediate policy target. Finally, a major objective of this line of inquiry is to call into question - and, if appropriate, to redirect - the peculiar balance-sheet asymmetry of current economic research that almost always emphasizes money over credit, bank liabilities over bank assets, and public assets over public liabilities.

Section I presents data for the U.S. economy's total nonfinancial debt ratio and for its components by sector, and documents the ratio's strong stability through comparisons based on several different methodologies. Section II sketches the simple outlines of three alternative approaches to explaining this phenomenon: specifically, an "ultrarationality" hypothesis, a "capital leveraging" hypothesis, and an "asset demand" hypothesis. Section III briefly inspects some evidence, based on U.S. household and corporate sector balance sheet data, that may bear on the adequacy of these possible explanations; it is important to emphasize at the outset, however, that this paper stops well short of rigorously developing and testing any specific hypothesis. Section IV briefly summarizes the paper's principal findings, re-emphasizes some important caveats, and goes on to assess the prospects for unravelling the underlying relationships among money, credit and nonfinancial economic activity. 
I. The Stability of the Total Debt Relationship

The Basic Data. Table 1 presents data showing the yearend indebtedness of U.S. nonfinancial borrowers, as a ratio to fourth-quarter gross national product (and multiplied by 100), for each of the twenty-six years in the standard sample period beginning after the Treasury-Federal Reserve Accord freed monetary policy from the wartime constraint of supporting government bond prices. The first column of the table shows the total credit market indebtedness of all U.S. nonfinancial borrowers. The next five columns present comparable data dividing this total into the respective indebtedness of each of five specific borrowing sectors. The table's final column shows, as a memorandum item, comparable data (not included in the total in the first column) for the debt issued in U.S. markets by foreign borrowers. $^{2}$ Figure 1 plots the total nonfinancial debt ratio and its five components by sector.

These data are "net" in the sense that they net out financial intermediation. In other words, the data include such items as a household's mortgage issued to a bank, or a corporation's bonds sold to an insurance company, but they exclude any liability issued in turn by the bank or the insurance company in order to finance that lending activity. The data also exclude debt issued by separate financial subsidiaries of nonfinancial corporations, as well as by federally sporsored credit agencies and mortgage pools. The data are "gross," however, in the sense that they include all of an individual household or firm's outstanding credit market liabilities, not just any excess of liabilities over either financial or total assets, and also in the sense that they include one household's borrowing from another or one firm's borrowing from another. 
The strong stability of the total nonfinancial debt ratio, shown in the top line in Figure 1 and the first column of Table 1 , stands out in stark contrast to the variation of the individual sector components. The nonfinancial economy's reliance on debt, scaled in relation to economic activity, has shown almost no trend and but little variation during the past quarter century. During this period the total nonfinancial debt ratio has trended slightly upward, with a low of 133.4 in 1956 and a high of 145.9 in 1964. Not surprisingly, the ratio has also exhibited a slight cyclicality, typically rising a point or two in recession years (when gross national product, in the denominator, is weak). At 143.3, the most recent observation is nearly back at the 1964 high.

The individual components of this total, however, have varied in sharply different directions both secularly and cyclically. In brief, the secular postwar rise in private debt has largely mirrored a substantial decline, relative to economic activity, in public debt, while cyclical bulges in public debt issuance have mostly had their counterpart in the abatement of private borrowing. Households have almost continually increased their reliance on debt in relation to their nonfinancial activity throughout this period. Both corporations and unincorporated businesses have also issued steadily more debt, on a relative basis, except for temporary retrenchments during recession years. State and local governments steadily increased their relative debt issuing activity during the 1950s and 1960s, but have just as steadily reduced it during the 1970s. Except only for 1975 and 1976, the federal government has reduced its debt ratio in every year throughout the postwar period, although more slowly in years when recession has temporarily inflated its deficit (and, again, depressed gross national product in the denominator). These data on debt issuing activity by the 
TABLE 1

OUTSTANDING DEBT ISSUED BY U.S. NONFINANCIAL BORROWERS

\begin{tabular}{|c|c|c|c|c|c|c|}
\hline \multicolumn{7}{|c|}{ State } \\
\hline & & $\varepsilon$ & & & Other & \\
\hline otal & $\begin{array}{l}\text { Fed. } \\
\text { Govt. }\end{array}$ & $\begin{array}{l}\text { Local } \\
\text { Govt. }\end{array}$ & $\begin{array}{l}\text { House- } \\
\text { holds }\end{array}$ & $\begin{array}{l}\text { Corpor- } \\
\text { ations }\end{array}$ & $\begin{array}{l}\text { Busi- } \\
\text { nesses }\end{array}$ & $\begin{array}{l}\text { Memorandum: } \\
\text { Foreign }\end{array}$ \\
\hline
\end{tabular}

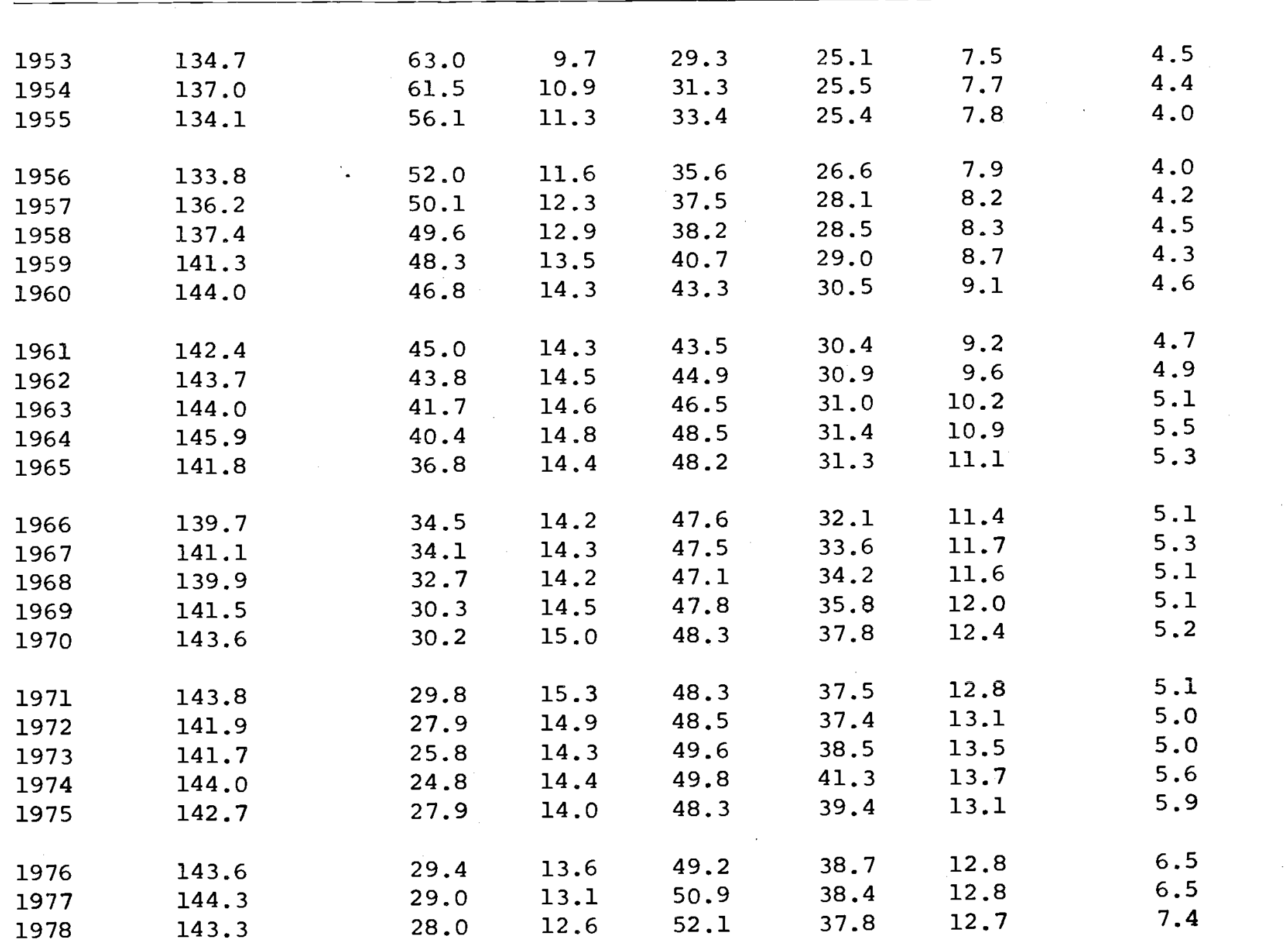

Notes: Ratios of yearend levels to fourth-quarter gross national product (seasonally adjusted annual rate), in percent.

Source: Board of Governors of the Federal Reserve System 


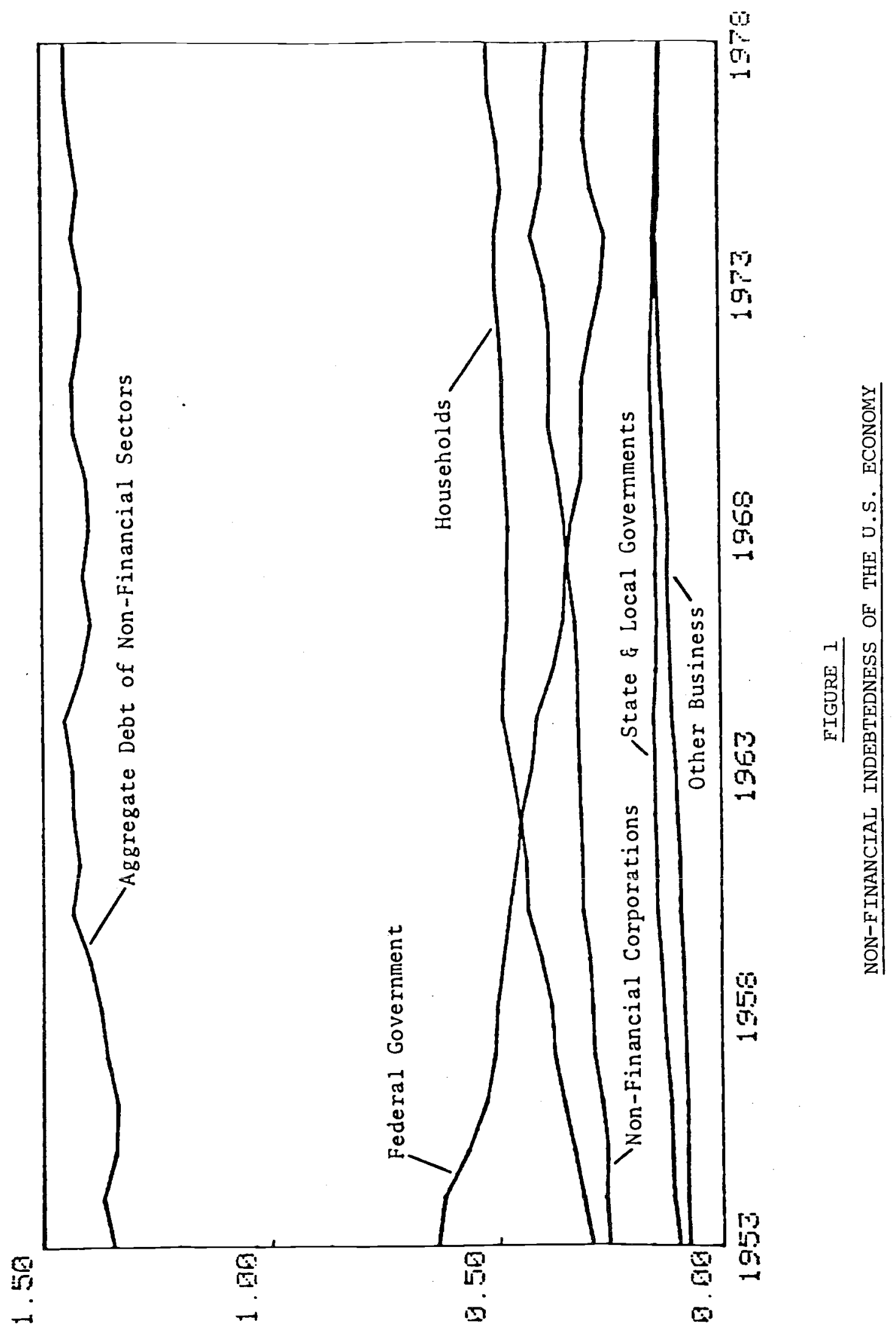


federal government are especially enlightening in the context of the recent widespread expressions of concern over the magnitude and import of the federal deficit. During the post World War II period, the federal debt ratio has in fact declined not just from 63.0 in 1953 but from 103.5 in 1946. Moreover, at 28.0 as of yearend 1978 , the ratio of federal indebtedness to gross national product stands once again at almost precisely its value in 1918. At the same time, it is also true that the past half decade has marked a departure from prior experience in an important way. The years 1975 and 1976 were the first in the postwar period in which the federal government's debt ratio actually rose, and the renewed decline in 1977 and 1978 has not yet reduced the ratio to its prerecession low.

Although the principal focus of this paper is on the post-Accord experience shown in Figure 1 , it is also useful to consider briefly the history of the debt ratio in a longer time frame. ${ }^{3}$ Figure 2 shows the size and composition of the U.S. nonfinancial debt ratio (with corporations and unincorporated businesses aggregated) for 1918-78. Apart from a one-time adjustment associated with the fall of prices after World War I, the U.S. nonfinancial economy's reliance on debt relative to economic activity has shown essentially no trend over these sixty years. At 143 as of yearend 1978, the debt ratio was virtually unchanged from 142 in 1921. Nonfinancial borrowers' outstanding debt rose significantly in relation to gross national product only during the depression years 1930-33, when gross national product itself not only was well below trend but also was falling too rapidly for the pay-down of debt to keep pace. ${ }^{4}$ Otherwise the economy's total nonfinancial debt ratio has remained roughly steady throughout this period, and the postAccord stability appears to be in large part a continuation of a pattern that dates back at least to the 1920s. 


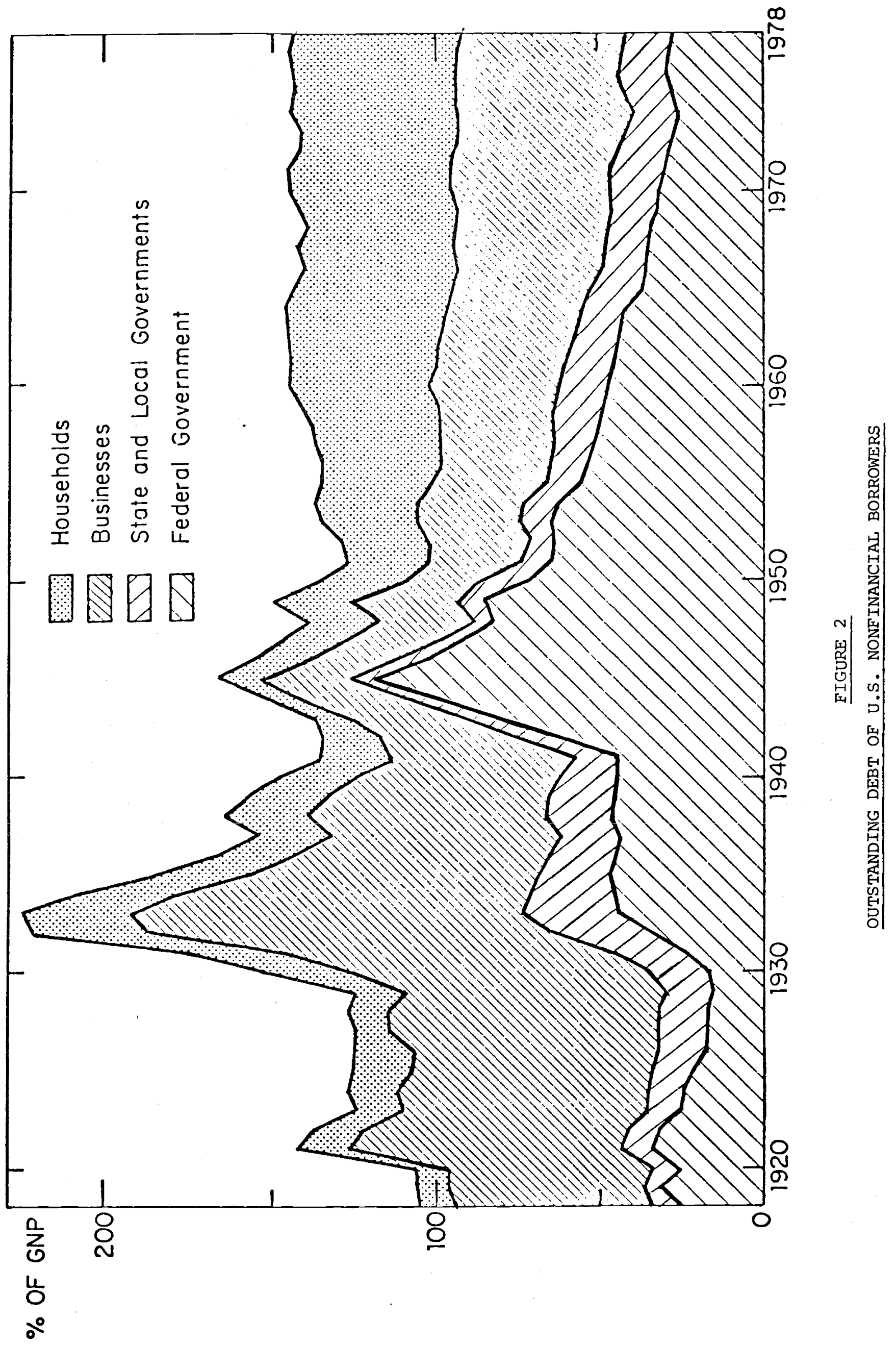


Comparison to Other Financial Ratios. Just how stable is the U.S. economy's aggregate debt ratio? The question that immediately arises is, stable in comparison to what? Given the traditional emphasis that economic analysis has placed on the relationship between money and economic activity, the usual money-income "velocities" provide a standard for comparison that is sufficiently familiar to be a good place to begin.

Table 2 summarizes the stability of the ratios to gross national product of ten financial aggregates by showing the coefficient of variation (standard deviation normalized by mean) for each ratio computed from both annual and quarterly U.S. data over the 1953-78 sample period lexcept for the M3 money stock, for which data begin only in 1959). In each case the table shows the coefficient of variation computed from raw data, and also computed from detrended data. Among the debt measures included in Table 2, "total net liabilities" is the total credit market indebtedness of nonfinancial U.S. borrowers, as shown in column 1 of Table 1; "total liabilities" is a broader measure that includes total net liabilities plus the credit market indebtedness of U.S. financial institutions;" "net non-federal liabilities" is a narrower measure that only includes the net liabilities of U.S. nonfinancial borrowers other than the federal government; net private liabilities" is the analogous measure that excludes not only federal but also state and local governments; and "bank credit" is the total of commercial bank loans and investments in the flow-of-funds accounts. Among the asset measures, the monetary base (currency plus bank reserves adjusted for changes in reserve requirements), M1 (currency plus demand deposits), M2 (M1 plus commerical bank time and saving deposits other than large negotiable certificates), and M3 (M2 plus time and saving deposits at thrift institutions) all follow standard definitions. 6 "Net financial assets" is a generally 
STABILITY OF U.S. ASSET AND LIABILITY RATIOS

\begin{tabular}{|c|c|c|c|}
\hline \multicolumn{2}{|c|}{ Annual } & \multicolumn{2}{|c|}{ Quarterly } \\
\hline Raw & Detrended & Raw & Detrended \\
\hline
\end{tabular}

\section{$\underline{\text { Assets }}$}

$\begin{array}{lcccc}\text { Monetary Base } & .165 & .051 & .168 & .052 \\ \text { Money (M1) } & .223 & .036 & .220 & .036 \\ \text { Money (M2) } & .043 & .029 & .044 & .028 \\ \text { Money (M3) } & .034 & .019 & .035 & .018 \\ \text { Net Financial Assets } & .015 & .014 & .016 & .015\end{array}$

\section{Liabilities}

Total Net Liabilities

Total Liabilities

Net Non-federal Liabilities

Net Private Liabilities

Bank Credit

$\begin{array}{llll}.025 & .018 & .020 & .019 \\ .052 & .016 & .054 & .018 \\ .119 & .041 & .123 & .041 \\ .124 & .035 & .126 & .035 \\ .068 & .032 & .068 & .032\end{array}$

Note: Coefficient of variation of ratio to gross national product (seasonally adjusted quarterly data, fourth quarter for annual data, at annual rate).

Data from Board of Governors of the Federal Reserve System. Sample period is 1953-1978 (1959-78 for M3). 
broader measure that includes total holdings of currency, deposits, and credit market debt instruments by all U.S. nonfinancial holders (specifically, the five sectors broken out in Table 1); it is "net" in the analogous sense that it excludes assets held by financial institutions, and therefore nets out financial intermediation.

For both annual and quarterly data, the coefficients of variation reported in Table 2 show an immediate contrast between those financial aggregates that exhibit time trends in their respective gross national product "reciprocal valocities" - including the monetary base, the Ml money stock, net non-federal liabilities, and net private liabilities - and those that apparently have little or no trend. Judged on the basis of the coefficients of variation computed from ratios of the raw data, the total net liabilities measure (from the first column of Table 1) displays the second steadiest relationship to gross national product out of the ten aggregates included in Table 2. The only one that is superior is the corresponding net aggregate on the asset side. None of the subtotals on either the money or the credit side, including the much heralded M2 money stock, exhibits the stability of the two economy-wide net totals. The coefficients of variation computed from the detrended ratios are more closely clustered, but again the net financial assets measure shows the greatest stability, and total net liabilities follows closely behind. After detrending, however, the total liabilities measure including the credit market debt of intermediaries shows marginally more stability than the corresponding net measure excluding them. Detrending improves the stability of the ratios based on the other measures also, but in no case other than the M3 money stock (for which the sample period is shorter) by enough even to come close to the range of the three economy-wide aggregates. In light of 
the increased attention recently paid by many economists to the monetary base, it is interesting to note that the stability of the base ranks tenth out of ten among the detrended series, in both the annual and the quarterly data.

The Covariance of Public and Private Debt Ratios. An argument for the stability of an aggregate inevitably relies on some notion of negative covariance among that aggregate's components. In the case of the economy's total nonfinancial debt ratio, as shown in Figure 1 and Table 1, what makes the stability of the ratio so interesting is in part the lack of stability among the respective debt ratios of the several individual nonfinancial sectors. Stability of the total debt ratio requires that movements in any one sector's debt relative to economic activity typically be offset by movements in the opposite direction in at least some other sector's debt. Although casual inspection of Figure 1 and Table 1 suggests the appearance of such a negative covariance relationship, the question is sufficiently important to warrant more careful investigation.

A useful approach to analyzing interrelationships among economic time series in this context is the vector autoregression. ${ }^{7}$ In brief, the vector autoregression methodology first expresses each of a system of variables as a function of lagged values of itself, lagged values of the other variables, and a disturbance term; then solves this representation to express each variable as a function of the entire history of the disturbances associated with it and the other variables; and, finally, investigates the direction and magnitude of the response of each variable to given independent shocks, or "innovations," to any or all variables in the system. The vector autoregression is straightforward to estimate empirically, and simulation of the solved-out system can then show whether innovations in particular variables 
result in system-wide responses consistent with specific hypotheses under investigation.

Although in principle it would be possible to apply this vector autoregression methodology to as full a disaggregation of the total nonfinancial debt ratio as could be estimated with the available data - for example, the five-sector breakdown used in Table 1 - the resulting profusion of partial relationships would shed little light on the basic question of whether a negative covariance between some nonfinancial sector's debt ratio and some other's acts to preserve stability over time in the total. A simpler approach, which not only renders the results more easily understandable but also provides potentially useful insights for the discussion of behavioral hypotheses in Sections II and III below, is to disaggregate only so far as to distinguish the federal government's debt ratio and that of the private nonfinancial sector (here including state and local governments). The resulting vector autoregression is

$$
\left[\begin{array}{l}
\left(L^{G} / Y\right)_{t} \\
\left(L^{P} / Y\right)_{t}
\end{array}\right]=\left[\begin{array}{l}
\alpha_{1} \\
\alpha_{2}
\end{array}\right]+\left[\begin{array}{ll}
B_{11} & B_{12} \\
B_{21} & B_{22}
\end{array}\right]\left[\begin{array}{l}
\left(L^{G} / Y\right) \\
t-1 \\
\left(L^{P} / Y\right)_{t-1}
\end{array}\right]+\left[\begin{array}{l}
\mu_{1 t} \\
\mu_{2 t}
\end{array}\right]
$$

where $L$ is nonfinancial debt ( $L$ for liabilities), $Y$ is nominal income (again measured by gross national product), the $G$ and $P$ superscripts respectively indicate the government and private sectors, the $\mu_{i}$ are disturbances, the $\alpha_{1}$ are fixed scaiar coefficients to be estimated, and the $B_{i j}$ are fixedcoefficient lag operator polynomials to be estimated. Solution of the autoregression (1), once it is estimated, yields a moving-average representation of the form 


$$
\left[\begin{array}{l}
\left(L^{G} / Y\right)_{t} \\
\left(L^{P} / Y\right)_{t}
\end{array}\right]=\left[\begin{array}{l}
\xi_{1} \\
\xi_{2}
\end{array}\right]+\left[\begin{array}{ll}
\theta_{11} & \theta_{12} \\
\theta_{21} & \theta_{22}
\end{array}\right]\left[\begin{array}{l}
\mu_{1 t} \\
\mu_{2 t}
\end{array}\right]
$$

where the $\xi_{i}$ and $\theta_{i j}$ are respectively fixed scalar coefficients and fixedcoefficient lag operator polynomials derived from recursive substitution of the $\alpha_{i}$ and $B_{i j}$ from (1) to express both $L G / Y$ and $L^{P} / Y$ as functions of the current values and past histories of both $\mu_{1}$ and $\mu_{2}$. Although the normalization convention imposed in (1) in order to estimate the system constrains the zero-lag elements of the four polynomials to $\theta_{11}=\theta_{22}=1$ and $\theta_{12}=\theta_{21}=0$, so that $\mu_{1}$ is "the $L^{G} / Y$ disturbance" and $\mu_{2}$ "the $L^{P} / Y$ disturbance" in the usual sense, in general the $\mu_{1}$ and $\mu_{2}$ series generated in the estimation of (1) are not independent. Simulations of (2) to trace the time paths of $L^{G} / Y$ and $L^{P} / Y$ resulting from specific movements of $\mu_{1}$ and $\mu_{2}$ would contain all the information that the vector autoregression system can provide, but it is easier to think intuitively about the implications of such a simulation when it is possible to identify as its driving force an independent innovation in either $L^{G} / Y$ or $L^{P} / Y$. Hence it is useful either to subtract out of $\mu_{1}$ that part of its variation that is correlated with $\mu_{2}$ so as to leave the residual to represent the independent innovation in $L^{G} / Y$ or, alternatively, to subtract out of $\mu_{2}$ that part of its variation that is correlated with $\mu_{1}$ so as to leave the residual to represent the independent innovation in $L^{P} / Y$. The orthogonalization of (2) that extracts the independent $L^{G} / Y$ innovation (say, $\left.\varepsilon_{1}\right)$, for example, is simply

$$
\left[\begin{array}{l}
\left(L^{G} / Y\right)_{t} \\
\left(L^{P} / Y\right)_{t}
\end{array}\right]=\left[\begin{array}{l}
\xi_{1} \\
\xi_{2}
\end{array}\right]+\left[\begin{array}{ll}
\phi_{11} & \phi_{12} \\
\phi_{21} & \phi_{22}
\end{array}\right]\left[\begin{array}{l}
\varepsilon_{1 t} \\
\varepsilon_{2 t}
\end{array}\right]
$$

where the $\xi_{i}$ are again as in (2), the $\phi_{i j}$ elements for each lag follow from 
the corresponding $\theta_{i j}$ according to

$$
\left[\begin{array}{ll}
\phi_{11} & \phi_{12} \\
\phi_{21} & \phi_{22}
\end{array}\right]=\left[\begin{array}{ll}
\theta_{11} & \theta_{12} \\
\theta_{21} & \theta_{22}
\end{array}\right]\left[\begin{array}{ll}
1 & \lambda \\
0 & 1
\end{array}\right]
$$

and the $\varepsilon_{i}$ innovations follow from the $\mu_{i}$ disturbances according to

$$
\left[\begin{array}{l}
\varepsilon_{1 t} \\
\varepsilon_{2 t}
\end{array}\right]=\left[\begin{array}{cc}
1 & -\lambda \\
0 & 1
\end{array}\right]\left[\begin{array}{l}
\mu_{1 t} \\
\mu_{2 t}
\end{array}\right]
$$

for

$$
\lambda=\frac{\operatorname{cov}\left(\mu_{1}, \mu_{2}\right)}{\operatorname{var}\left(\mu_{2}\right)} .
$$

The alternate orthogonalization that extracts $\varepsilon_{2}$ as the independent innovation in $L^{P} / Y$ simply reverses the off-diagonal positions of 0 and $\lambda$ in (4) and (5), with $\operatorname{var}\left(\mu_{1}\right)$ replacing $\operatorname{var}\left(\mu_{2}\right)$ in the denominator of $(6)$.

Table 3 presents simulation results based on the vector autoregression system (1) estimated using U.S. annual data for 1953-78 (1960-78 for M3) with two years of lags on each variable in each equation. The top half of the table presents the results of simulating the system's moving-average representation (3), orthogonalized as in (4) and (5), to show the time paths of the responses of both $L^{G} / Y$ and $L^{P} / Y$ to a $1 \%$ innovation in $L / Y$. By construction, ${ }_{L}^{P} / Y$ remains unaffected contemporaneously, so that in the initial year the economy's total nonfinancial debt ratio $\left(L^{G}+L^{P}\right) / Y$ also rises by $1 \%$. Within the next several years, however, a gradual decay in $L G / Y$ and an offsetting downward move in $I^{P} / Y$ combine to eliminate virtually all of the initial bulge in the total nonfinancial debt ratio caused by a positive shock to the government component. This pattern appears to be consistent with an underlying model in which the innovation in the government debt ratio due to 
DYNAMIC RESPONSES OF TOTAL NET LIABILITIES RATIO

\begin{tabular}{ccc} 
& Ratio to Nominal Income of: \\
\hline Net & Net & Total \\
Federal & Non-federal & Net \\
Liabilities & Liabilities & Liabilities
\end{tabular}

A. Response to 1\% Impulse Innovation in Net Federal Liabilities Ratio: $\underline{\text { Year }}$

$\begin{array}{lccc}1 & 1.008 & .00 \% & 1.008 \\ 2 & .63 & .06 & .69 \\ 3 & .51 & -.11 & .40 \\ 4 & .46 & -.25 & .21 \\ 5 & .43 & -.32 & .12\end{array}$

B. Response to $1 \%$ Impulse Innovation in Net Non-federal Liabilities Ratio: Year

1

2

3

4

5
.008

$-.40$

$-.47$

$-.42$

$-.34$
1.008

1.128

.81

.50

.29
$1.00 \%$

.72

.34

.08

$-.05$ 
deficit spending subsequently stimulates income, thereby lowering the private debt ratio unless private borrowing increases in pace, but it may be consistent with other models too. The important feature of these results here is simply that they document a negative dynamic covariance in the two major components of the economy's aggregate nonfinancial debt ratio.

The bottom half of Table 3 presents the results of analogous simulations based on the alternative orthogonalization that extracts $\varepsilon_{2}$ as the independent innovation in $L^{P} / Y$. . In this case the positive innovation in $L^{P} / Y$ exhibits some momentum effect in the second year (although the relevant standard error does not permit rejecting at any reasonable confidence level the null hypothesis that the second-year $L^{P} / Y$ value is 1.00 instead of 1.12 ), but thereafter the decay is fairly rapia. Moreover, the offsetting negative movement in $L / Y$ appears immediately (that is, immediately after the one-period delay imposed by construction) and in substantial magnitude. Hence the total nonfinancial debt ratio achieves its original value again fairly quickly after a shock to private borrowing also. In sum, both sets of results presented in Table 3 document the existence of offsetting movements within the aggregate debt ratio and hence both quantify and reinforce the casual impression of negative covariance given by Figure $I$ and Table 1 .

Comparison of Nominal Income Regressions. Simple ratios of precisely contemporaneous observations may well fail to capture the relevant concept of "stability" in the relationship among variables that move over time with some general lead or lag pattern between them. Table 4 presents summary statistics for single equations, estimated using U.S. quarterly data for 1953-78 (except for $\mathrm{M} 3$ ), relating the growth of nominal gross national product to a moving average of the growth of each of the ten financial aggregates listed in Table 2, plus a moving average of a fiscal policy measure. The equations are 


\section{TABLE 4}

SUMMARY STATISTICS FOR INCOME REGRESSIONS

SE

$\underline{\mathrm{R}}^{2}$

DW

Assets

Monetary Base

.00949

.32

1.65

Money (MI)

.00879

.42

1.86

Money (M2)

.00909

.38

1.74

Money (M3)

.00770

.38

1.93

Net Financial Assets

.00846

.46

1.98

\section{Liabilities}

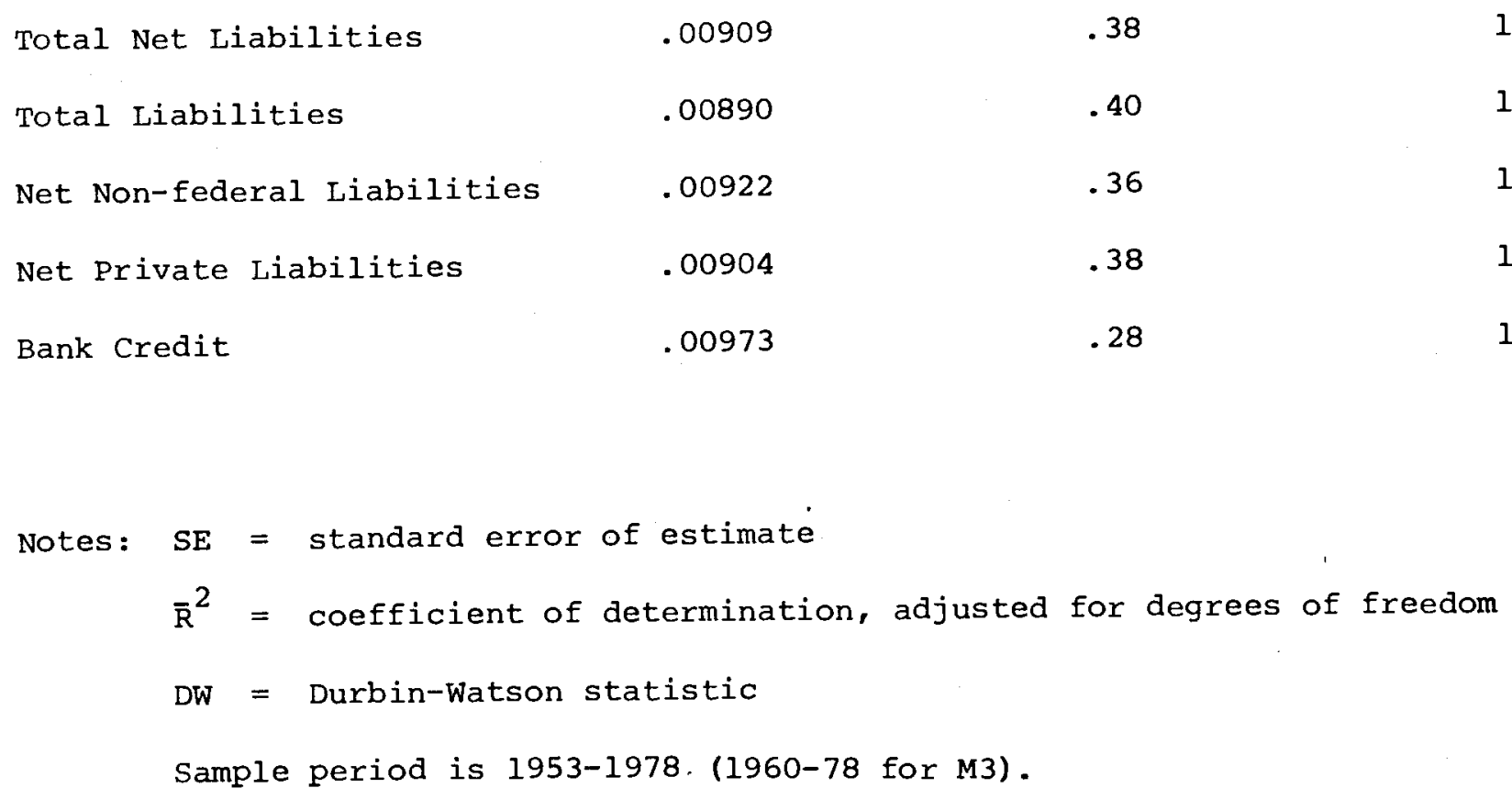

Bank Credit

.00973

.28

1.53 
estimated in the familiar form

$$
\Delta \ln Y_{t}=\alpha+\sum_{i=0}^{4} \beta_{i} \Delta \ln F_{t-i}+\sum_{i=0}^{4} \gamma_{i} \Delta \ln E_{t-i}+\mu_{t}
$$

where $F$ is any of the five asset aggregates or five debt aggregates; $E$ is federal government expenditures measured on a full employment basis; $\alpha$, the $\beta_{i}$ and the $\gamma_{i}$ are estimated scalar coefficients; and the $\beta_{i}$ and $\gamma_{i}$ are both constrained to lie along fourth-degree polynomials with the implied $\beta_{-1}=$ $\beta_{5}=\gamma_{-1}=\gamma_{5}=0$

The implications of the results shown in Table 4 for the stability of the different aggregates are, with few exceptions, roughly comparable to the results of the simple ratio tests shown in Table 2. Net financial assets again appears to have the most stable relation to gross national product, with total liabilities, total net liabilities, and the M2 and M3 money stocks ranking nearly as before. ${ }^{8}$ The most noticeable changes from the rankings shown in Table 2 are the strong performance of the Ml money stock, which ranks second on this criterion, and the poor performance of bank credit, which here ranks last.

It would be interesting to know to what extent the rankings shown in Table 4 represent a consistent stability or lack thereof over the entire 1953-78 sample, as opposed to one or more significant shifts in otherwise fairly stable relationships. The Durbin-Watson statistic for bank credit, for example - the measure ranking tenth - shows significant evidence of positive serial correlation of the equation's residuals. Similarly, the Durbin-Watson statistic for the monetary base - the measure ranking ninth shows possible evidence of serial correlation. A recent accumulation of evidence has shown that the Federal Reserve System's change in 1970, to a 
policy strategy placing greater emphasis on monetary aggregates, was more than merely rhetorical as some critics have alleged. ${ }^{9}$ This change may well have altered some of the relationships under consideration here. In addition, it is possible that the Federal Reserve's removal of Regulation $Q$ interest ceilings from most large negotiable certificates of deposit in 1970 may also have had an effect on some of these relationships. ${ }^{10}$ Hence 1970 is a plausible time to expect a break on a priori grounds.

The first column of Table 5 presents F-statistics for a test of the null hypothesis of no break at the beginning of 1970 in the regression equations reported in Table 4. The only three measures for which it is not possible to reject this null hypothesis at the .05 level are the two overall net asset and liability totals (for which the margin of non-rejection is minimal) and M3 (which has a much shorter pre-1970 sample period). For all seven other measures the data provide significant evidence of a break at 1970 . The remaining columns of Table 5 present summary statistics for the analogous regressions run over the shorter 1970-78 sample period. It is interesting that the standard errors reported here are typically of about the same magnitude as those shown in Table 4, but the fraction of the variation of gross national product growth explained is much lower. These results again confirm the strong stability of net financial assets and total liabilities, and the only slightly less strong stability of the other credit measures (this time including bank credit). On the money side, only the Ml money stock performs comparably. For this short sample period the M2 money stock and the monetary base rank respectively ninth and tenth among the ten measures examined.

In part because of the extent to which regressions of the form (7) have been discredited by a variety of criticisms, ${ }^{11}$ researchers examining the money-income (or, here, debt-income) relationship have increasingly turned to 
F-Statistic for Break at 1970
1970-78 Summary Statistics

$\underline{\mathrm{SE}} \quad \overrightarrow{\mathrm{R}}^{2}$

Assets

Monetary Base

Money (MI)

Money (M2)

Money (M3)

Net Financial Assets

\section{Liabilities}

Total Net Liabilities
Total Liabilities
Net Non-federal Liabilities
Net Private Liabilities
Bank Credit
$2.13^{\star}$
$2.67^{\star}$
$2.79^{\star}$
1.59
2.08

.00993

.02

2.14

.00897

.20

2.41

.00962

.08

2.09

.00947

.11

2.17

.00840

.30

2.42

$\begin{array}{llll}2.04 & .00899 & .20 & 2.48 \\ 2.29^{*} & .00828 & .32 & 2.45 \\ 4.82^{* *} & .00894 & .21 & 2.54 \\ 4.85^{* *} & .00909 & .18 & 2.47 \\ 6.14^{* *} & .00911 & .18 & 2.16\end{array}$

Notes: $*$ significant at .05 level.
$\star \star \quad$ significant at.01 level. 
methods that relate the variation of income not to the entirety of the variation of money but to that part of it which cannot already be deduced either from the past history of money itself or from the joint past history of both money and income. A more general representation of (7) that is consistent with this interpretation (although for convenience omitting the fiscal policy variable) is the vector autoregression

$$
\left[\begin{array}{ll}
\ln & F_{t} \\
\ln Y_{t}
\end{array}\right]=\left[\begin{array}{l}
\alpha_{1} \\
\alpha_{2}
\end{array}\right]+\left[\begin{array}{ll}
B_{11} & B_{12} \\
B_{21} & B_{22}
\end{array}\right]\left[\begin{array}{ll}
\ln & F_{t-1} \\
\ln & Y_{t-1}
\end{array}\right]+\left[\begin{array}{l}
\mu_{1 t} \\
\mu_{2 t}
\end{array}\right]
$$

where the $\alpha_{i}$ and $B_{i j}$ are again as in (1). ${ }^{12}$ The moving-average representation of (8), orthogonalized so as to extract the independent innovation particular to $F$ (here $\varepsilon_{1}$ ), is then

$$
\left[\begin{array}{ll}
\ln & F_{t} \\
\ln & Y_{t}
\end{array}\right]=\left[\begin{array}{l}
\xi_{1} \\
\xi_{2}
\end{array}\right]+\left[\begin{array}{ll}
\phi_{11} & \phi_{12} \\
\phi_{21} & \phi_{22}
\end{array}\right]\left[\begin{array}{l}
\varepsilon_{1 t} \\
\varepsilon_{21}
\end{array}\right]
$$

where the $\varepsilon_{i}, \xi_{i}$ and $\phi_{i j}$ are as in (3), orthogonalized as in $(4)-(6)$.

Table 6 presents summary simulation results based on system (1) estimated using the same quarterly data for the same ten U.S. financial aggregates as in Tables 4 and 5, with eight quarters of lags on each variable in each equation. Instead of reporting the individual response patterns for $F$ and $Y$ separately and then for the "reciprocal velocity" ratio $F / Y$, which would be analogous to the procedure followed in Table 3 since $\ln (F / Y)=$ In $F$ - In $Y$, for convenience the table reports only the response of $F / Y$. Moreover, instead of presenting the complete time path, the table presents values only for the initial quarter and then for the final quarter in each of the first five years.

The top half of Table 6 shows the time path followed by each of the 


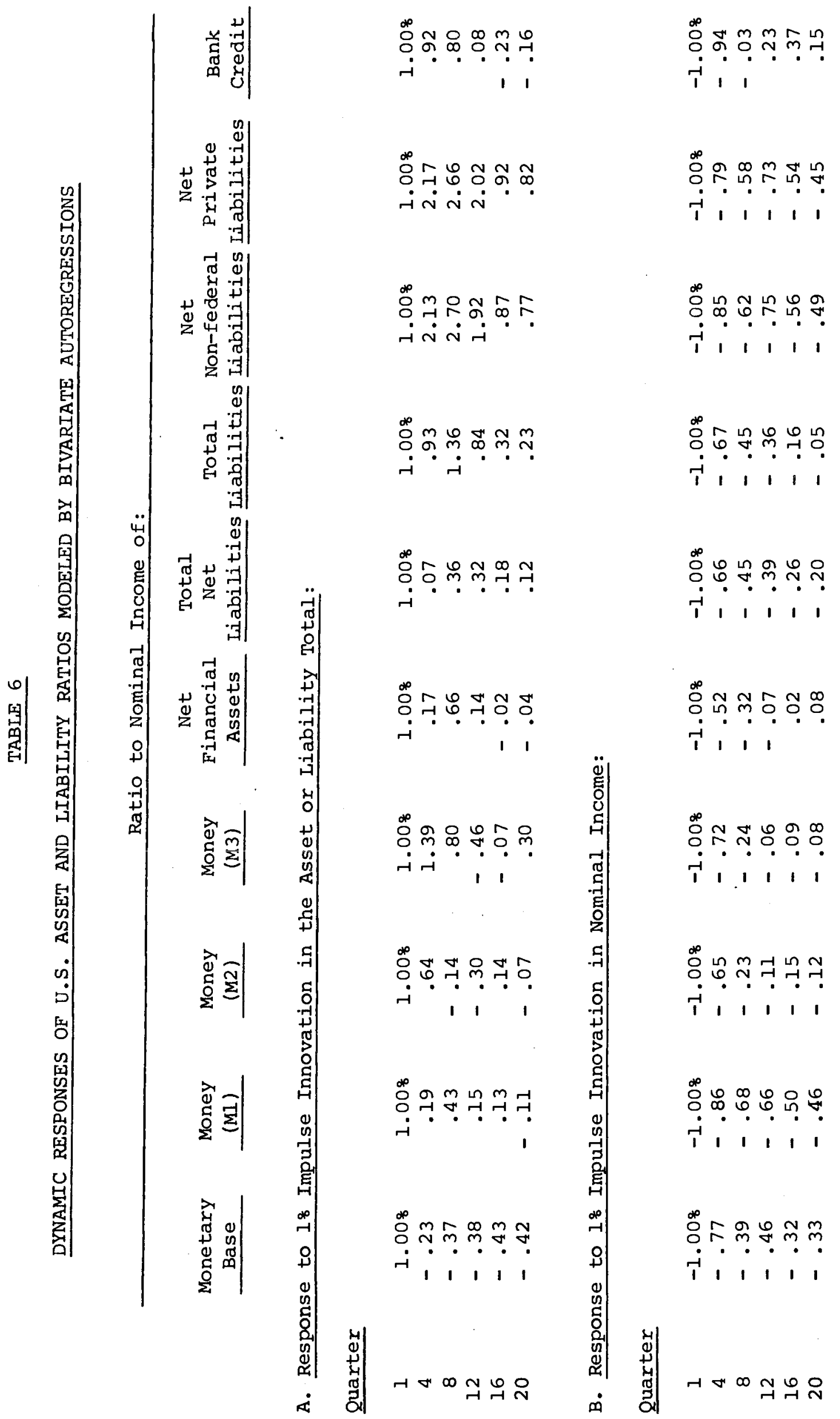


ten financial aggregate ratios in response to a 18 innovation in the respective aggregate. By construction, Y remains unaffected contemporaneously, so that in the initial quarter each $F / Y$ ratio also rises by $1 \%$. After several quarters, however, the bulge disappears from most of the ratios as $Y$ rises or $F$ declines, or both. In the absence of a largely arbitrary judgment of the exact time horizon that is relevant to the analysis, it is impossible to interpret these results in other than a descriptive way. Even so, the comparisons are quite suggestive. Among the five asset ratios, those for the $M 1$ and $M 2$ money stocks and for the net asset total all decline rapidly albeit irregularly, while the ratio for the M3 money stock continues to rise through the first year before then declining. The monetary base ratio over-corrects (although not significantly so at usual confidence levels) and then remains persistently negative. In sum, except perhaps for the over-correction of the monetary base ratio, there is little to distinguish the respective simulation patterns shown by these five financial asset ratios.

The same is not true for the five debt ratios, however. Here only the total net liabilities ratio - again, the series documented in Table 1 and Figure 1 - and the bank credit ratio (though to a lesser extent) return rapidly and monotonically to their initial values after a shock to the relevant aggregate. What is especially interesting in these results is the contrast between the performance of the ratio for total net liabilities and the ratios for net non-federal liabilities and net private liabilities (both of which are just components of total net liabilities) as well as the total liabilities measure consisting of total net liabilities plus the liabilities of financial intermediaries. Both the net private liabilities ratio and the slightly broader net non-federal liabilities ratio continue to move further away from their initial values for two years in response to an innovation in 
the relevant aggregate, and neither shows any significant return to its initial value within five years - hardly a demonstration of "stability." Once net federal liabilities are included as well, however, the total net liabilities ratio exhibits just as much stability in this context as does any of the five asset ratios. Moreover, proceeding to broaden the liability measure further by including intermediaries' debt only results in lessened apparent stability.

Among the various liability measures considered, therefore, these results suggest that there is indeed something unique about total net (that is, nonfinancial sector) liabilities. It is as if the Ml money stock ratio were sharply unstable, but adding commercial bank time and saving deposits to form the M2 money stock ratio yielded stability, and further adding thrift institution deposits to form the $M 3$ money stock ratio destroyed that stability - none of which appears to happen. Hence not only does the total net liabilities ratio exhibit just as much stability as any of the five asset ratios in these vector autoregression tests, it does so uniquely among the various debt aggregates tested.

The lower half of Table 6 presents the results of analogous simulations based on the alternative orthogonalizaiton of (9) that extracts $\varepsilon_{2}$ as the independent innovation in $Y$. In this case, by construction, it is $F$ that remains unaffected contemporaneously, so that in the initial quarter a 18 innovation in $\mathrm{Y}$ generates a 18 decline in $F / Y$. Subsequently, however, $F / Y$ rises as the innovation in $\mathrm{Y}$ decays or $\mathrm{F}$ rises, or both. The paths traced by the ten asset or liability ratios are sufficiently similar, however, that there appears to be little ground for distinguishing among them here. Evidence from More Complete Vector Autoregression Systems. One element in the tendency of recent research to eschew reliance on simple nominal income regressions of the form (7) has been an increasing reluctance 
to focus on the relationship between money (or, here, debt) and nominal income without distinguishing between the real and price components in nominal income variation. Table 7 presents simulation results that are analogous to those shown in Table 6 but based on the trivariate system

$$
\left[\begin{array}{ll}
\ln & F_{t} \\
\ln & x_{t} \\
\ln & P_{t}
\end{array}\right]=\left[\begin{array}{l}
\alpha_{1} \\
\alpha_{2} \\
\alpha_{3}
\end{array}\right]+\left[\begin{array}{lll}
B_{11} & B_{12} & B_{13} \\
B_{21} & B_{22} & B_{23} \\
B_{31} & B_{32} & B_{33}
\end{array}\right]\left[\begin{array}{l}
\ln F_{t-1} \\
\ln x_{t-1} \\
\ln P_{t-1}
\end{array}\right]+\left[\begin{array}{l}
\mu_{2 t} \\
\mu_{3 t}
\end{array}\right]
$$

solved for the corresponding moving-average representation

$$
\left[\begin{array}{ll}
\ln & F_{t} \\
\ln & x_{t} \\
\ln & P_{t}
\end{array}\right]=\left[\begin{array}{l}
\xi_{1} \\
\xi_{2} \\
\xi_{3}
\end{array}\right]+\left[\begin{array}{lll}
\theta_{11} & \theta_{12} & \theta_{13} \\
\theta_{21} & \theta_{22} & \theta_{23} \\
\theta_{31} & \theta_{32} & \theta_{33}
\end{array}\right]\left[\begin{array}{l}
\varepsilon_{1 t} \\
\varepsilon_{2 t} \\
\varepsilon_{3 t}
\end{array}\right]
$$

where $P$ is the gross national product price deflator $(1972=100), x$ is real income $(Y / P)$, and all other symbols are exactly analogous to their counterparts in (8) and (9). Like Table 6, Table 7 again shows simulation results only for the various asset or liability ratios, in each case solved simply as $\ln [F /(X \cdot P)]=\ln F-\ln X-\ln P$. The estimation and sample period are again the same as for (8).

The three panels of Table 7 successively present results for the simulation of (11) orthogonalized to extract $\varepsilon_{1}$ as the independent innovation in $F$, to extract $\varepsilon_{2}$ as the independent innovation in $x$, and to extract $\varepsilon_{3}$ as the independent innovation in P. The responses of the asset or liability ratios to an innovation in the relevant aggregate, shown in panel $A$, resemble those shown in Table 6 for the analogous bivariate system. Considering the roles of real income and prices separately does little to alter the earlier impression of stability of the ratios for most of the asset aggregates and for 


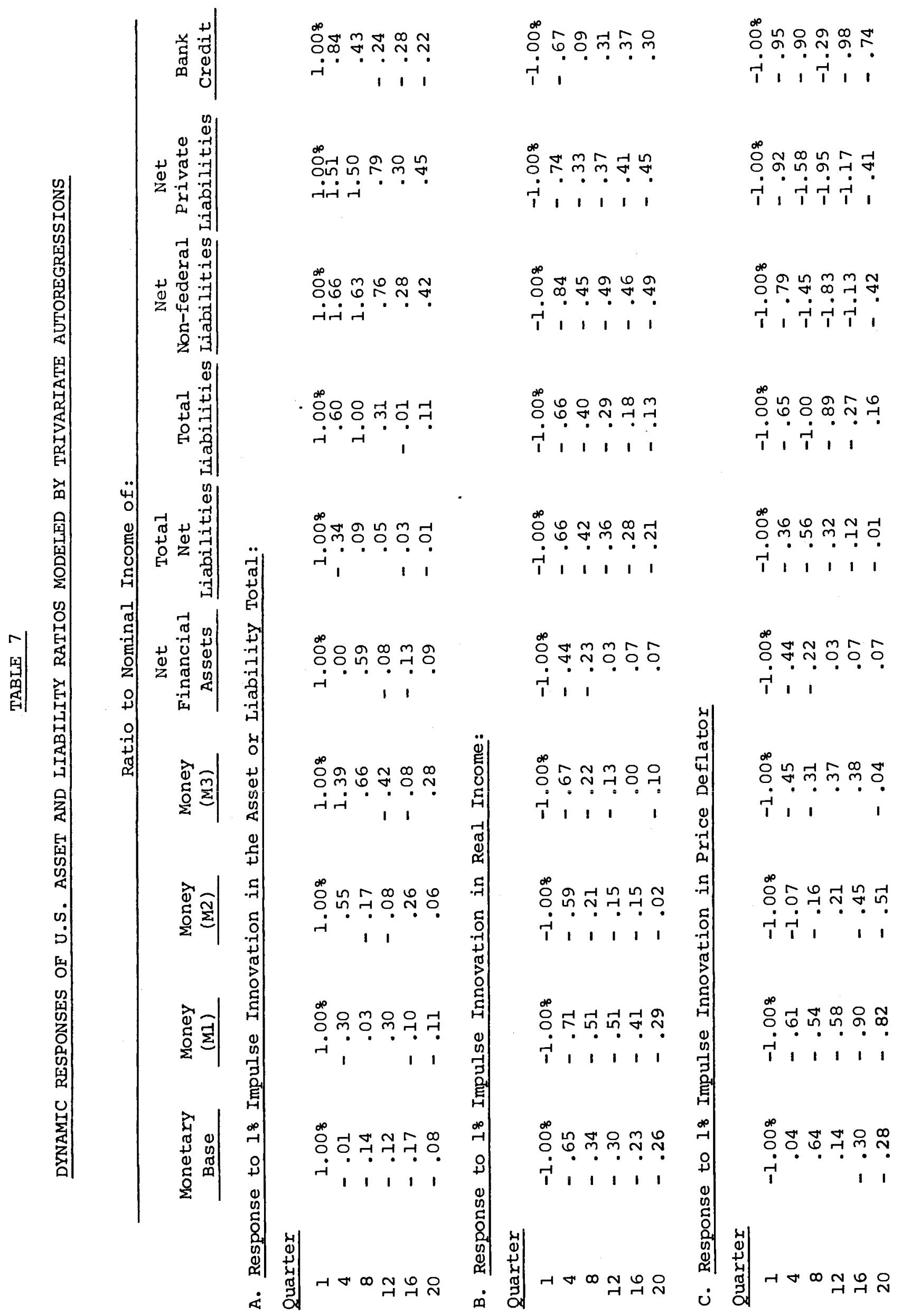


total net liabilities (and, to a lesser extent, bank credit), in contrast to instability of the ratios for liabilities measures that are components of the total net liabilities aggregate. The responses to an innovation in real income, shown in panel B, also largely resemble the responses shown in Table 6 resulting from an innovation in nominal income. Again there is little to distinguish the stability of one ratio from that of another in this context. The responses to an innovation in prices, shown in panel $C$, bear some resemblence (with appropriate sign changes) to the responses to innovations in the respective aggregates from panel A, although some interesting differences emerge. Once again the total net liabilities ratio appears to be quite stable despite strong instability in its two components. In addition, the net financial assets and monetary base ratios again appear stable, although with somewhat more (temporary) over-correction than before in the latter. The notable contrasts to the panel $\mathrm{A}$ results are the appearance of greater stability in the ratio for the $M 3$ money stock and less stability in the ratios for the $M I$ money stock and for bank credit.

Finally, Table 8 presents simulation results for a four-variable system including the Ml money stock, total net liabilities ( ${ }^{\text {TNF}}$ ), real income and prices, estimated and solved analogously to (10) and (11) for the vector $\left[\ln M_{t^{\prime}} \ln \mathrm{L}_{t}^{\mathrm{TNF}}, \ln \mathrm{X}_{t^{\prime}} \text { ln } \mathrm{P}_{t}\right]^{\prime}$. The four panels of the table show simulation results for the system orthogonalized successively to extract the independent innovations in $M, L^{T N F}, X$ and $P$. In each case the table shows the time paths of the individual responses of the four variables in the system, together with the "reciprocal velocity" ratios for the money and debt variables.

In response to a one-quarter innovation in the money stock (panel A), the money stock remains enlarged throughout the five years, debt exhibits a 

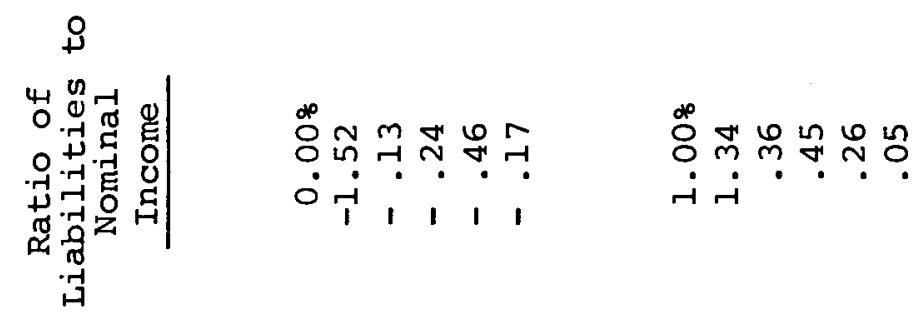

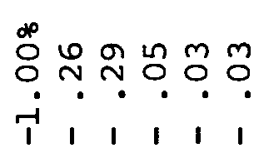

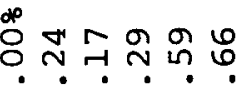

年, 11

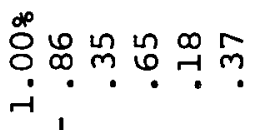

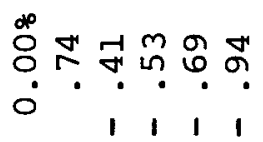

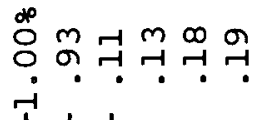

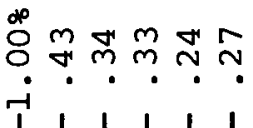

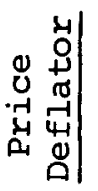

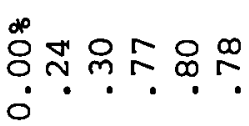

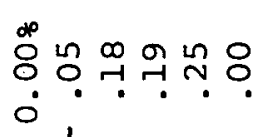

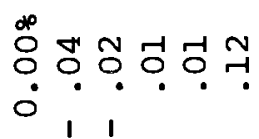

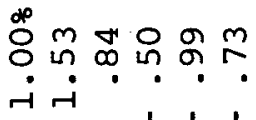

ㅇํㅇ요욤

.

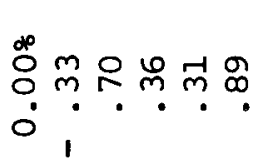

芯

ํำ

范

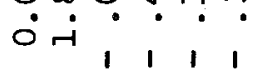

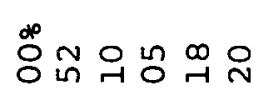
0. $\cdot$.

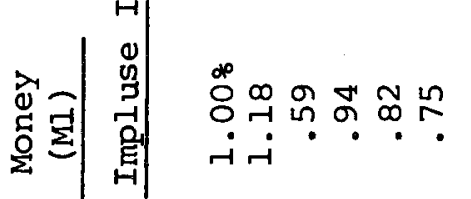

8

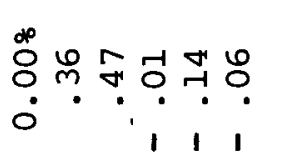

ํํㅇํㅇำ 군 군 $\circ:$

$\stackrel{\infty}{\circ} \stackrel{m}{\sim} \stackrel{\infty}{\sim} \stackrel{\circ}{m} \tilde{r}$ $\dot{0} \underset{1}{0} \dot{1}$

ㅇํㅇ ๙ூ

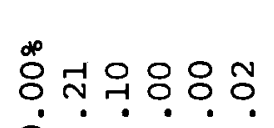
ठั 1 م.

ㅇํㅇ 의의 : 1011

윰 ०

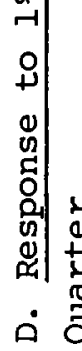


mostly temporary positive response in the first year only, real income is sharply higher in the first year but lower thereafter, and prices rise to a new higher level within three years. The money ratio therefore at first overcorrects (because of the strong real income response) and then stabilizes with some small (and insignificant) oscillations. The debt ratio first declines sharply but then returns essentially to its initial value. Here the money and debt ratios appear to be of comparable stability. In response to an analogous innovation in nonfinancial debt (panel B), the debt variable remains enlarged throughout the five years, both the money stock and prices are temporarily higher, and real income, after a small dip in the first year, is irregularly higher throughout. The debt ratio therefore continues to rise through the first year, but then declines fairly regularly toward its initial value. The money ratio is first higher, and then persistently lower. Here the debt ratio appears to be, if anything, more stable than the money ratio. Finally, the responses to innovations in real income (panel c) and in prices (panel D) provide little basis for judging the relative stability of the money and debt ratios.

Overview. What conclusion does this battery of descriptive statistics and assorted tests suggest for the stability of the relationship between the U.S. economy's total nonfinancial indebtedness and its underlying nonfinancial activity? At the very least, this collection of results indicates that the stability of this relationship is just as strong as the stability of comparable but more familiar relationships involving various definitions of the money stock or the monetary base. Beyond that, the data repeatedly suggest that the relationship for the total nonfinancial debt measure is more stable than that for any of its underlying components. 
II. Three Possible Explanations of the Stability of the Debt Ratio

Some Familiar Basics. A fairly standard element of many simple models of economic steady states is a fixed proportional relationship between the flow of income and the stock of wealth. ${ }^{13}$ Moreover, under assumptions involving such matters as the production process and the population age structure, a fixed proportional wealth-to-income relation may also be characteristic of models of steady-state growth. ${ }^{14}$ In either case the rationale stems from the familiar view that the chief motive for holding wealth is to derive the stream of services (broadly defined) that flow from various forms of wealth, and that the demand for such services by individual maximizers is (like the demand for nondurable consumption) proportional to income.

In the absence of claims issued by either the government or private participants in the economy, the "wealth" that is (or may be) proportional to income in such models consists entirely of tangible assets. In the presence of financial claims, however, the wealth concept that is most plausible to relate to income flows in this manner is presumably net worth, and exactly how to define net worth becomes a potentially important issue. In a basic model with financial claims but no financial intermediaries, the net worth relation is either again simply

$$
\mathrm{NW}=\mathrm{TA}
$$

if the private sector "sees through the shell" of government and treats the government's liabilities as if they were its own, or else

$$
N W=T A+L^{G}
$$

where NW is net worth, TA is tangible assets, and $L^{G}$ is again the government's liabilities. An alternative way of stating (13), when the government's holdings of financial assets are approximately zero, is

$$
N W=T A+F A-L^{P}
$$


where FA is total financial asset holdings and $L^{P}$ is again the private sector's financial liabilities. Since all financial claims must be held, 15

$$
L^{G}+L^{P}=F A \text {. }
$$

Finally, an alternative form of (15) that is relevant in the presence of financial intermediaries is

$$
L^{G}+L^{P}+L^{I}=F A^{P}+F A^{I}
$$

where $\mathrm{FA}^{\mathrm{P}}$ now distinguishes financial assets held by the private nonfinancial sector, and $\mathrm{L}^{\mathrm{I}}$ and $\mathrm{FA}^{\mathrm{I}}$ are respectively the liabilities owed and assets held by intermediaries. ${ }^{16}$ Nothing in (12)-(16) changes if all variables are measured as ratios to income - a convention that is to be understood whenever it is relevant in what follows.

In terms of these relationships, the basic phenomenon documented in Section $I$ is the strong stability of the sum $L^{P}+L^{G}$ (again, as ratios to gross national product) for the U.S. economy. The stability of this stockflow relationship raises issues that are in part reminiscent of those involved in the flow-flow relationship associated primarily with Denison [4] and subsequently studied by others. In addition, as was noted at the outset, its stability in comparison with financial measures more commonly used as a basis for monetary policy discussions raises issues about the use of the money stock (however defined) as the intermediate target variable, or more generally as the most important information variable, for the conduct of monetary policy. 17 Even as a matter of purely basic research into economic behavior, however, the results assembled in section I naturally lead to the question of why - in the scientific sense meaning "how" - the economy's total nonfinancial debt ratio turns out to be so stable.

An Ultrarationality Hypothesis. In their analysis of the stability of U.S. gross private saving in relation to gross national product typically 
known as "Denison's Law," David and Scadding [2] introduced an hypothesis of "ultrarationality" which, after appropriate transformation from a flow-flow context to a stock-flow context, also represents a possible explanation for the stability of U.S. nonfinancial indebtedness in relation to gross national product. Specifically, David and Scadding argued that individuals "see through the shell" of both government and the corporation, so that personal saving and corporate saving are close substitutes, as are personal consumption and taxes. Hence, as Denison had noted earlier, total gross private saving (the sum of personal saving plus corporate saving plus capital consumption) not only is more stable than its individual components but also is apparently unaffected by variations in the share of income absorbed by the government sector. Moreover, David and Scadding concluded that the apparent invariance of the gross private saving rate with respect to variations in the surplus or deficit position of the government sector, also noted by Denison, implies a close substitutability of private debt and public debt in private portfolios. This same concept of "seeing through the shell" represented by government and corporations also constitutes one possibie explanation for the stability of the economy's total nonfinancial debt ratio. If the private sector regards the debt of government as equivalent to its own debt, then its net worth statement in the form (14) should instead be

$$
N W=T A+F A-\left(L^{P}+L^{G}\right)
$$

or, given (15), simply (12) again. Moreover, if households regard the debt of corporations as equivalent to their own debt, then they will not distinguish between direct and corporate liabilities within $L^{P}$. Under this hypothesis, then, households would have viewed the decline of $L^{G}$ (here including both federal and state-local obligations) from $72.7 \%$ of the gross national product in 1953 to only $40.6 \%$ in 1978 as a decline in their own 
indebtedness, which they then slightly more than made up by increasing their direct indebtedness (including obligations of unincorporated businesses) from $36.8 \%$ to $64.8 \%$ and by having corporations increase the indirect component of $\mathrm{L}^{\mathrm{P}}$ from $25.1 \%$ to $37.8 \%$.

The essential point in this perspective is the existence of a stable ratio to income not just for some undefined "wealth" concept, as is usually assumed, or even for the more precise concept of net worth, but, in addition, for the total assets and total liabilities components of net worth separately. 18 Following the "services flow" rationale noted above, the main idea here is that assets and liabilities each separately yield streams of services (presumably negative for the liabilities), and that individual maximizers will seek a quantity of each that is proportional to income. Hence, given any variation in the government share of the overall liabilities total, for whatever purposes indicated by public policy objectives, the private sector consisting of households and the corporations that the households own will simply adjust by issuing enough debt to offset the government's action. Yet a further elaboration of the same basic idea that changes nothing fundamental would be to view corporations as also responding to independent objectives or influences (for example, tax laws), and households as then adjusting their debt positions to offset the given actions of both the government and the corporations. In either case, the nonfinancial economy will seek (and achieve) a stable ratio of its aggregate liabilities to income regardless of the composition of that aggregate.

The "ultrarationality" hypothesis is interesting for a number of reasons. From a purely behavioral standpoint, for example, it carries strong implications about individuals' perceptions and about the motivating forces underlying familiar aspects of portfolio behavior. Moreover, as David and 
Scadding pointed out, it also implies that "ex ante crowding out" renders fiscal policy impotent in both the short and long run.

A Capital Leveraging Hypothesis. In addition to the extreme view that it embodies of individuals' ability to "see through the shell" of both government and corporations, the ultrarationality hypothesis described above rests importantly on two strong assumptions. First, it relies on the presumption of a general absence of effective credit market constraints. People are implicitly assumed not only to want to substitute their own (and their corporations') indebtedness for government debt but also to be able to do so. Second, it assumes not only that people want to hold their net worth, total assets and total liabilities stable in relation to income but also, because financial liabilities owed equal financial assets held, that they hold their tangible assets and financial assets separately in stable respective relations to income.

An alternative route to explaining the observed stability of the U.S. economy's nonfinancial debt ratio is to abandon these two assumptions, as well as that of "seeing through the shell," and instead to assume, first, that the private sector does face credit market constraints and, second, that it does not necessarily hold its asset ratio stable. If the private sector does not view government debt as equivalent to its own, then it is clear from (13) that, if $\mathrm{L}^{\mathrm{G}}$ declines (as has happened in the United States during the 1953-78 sample period examined in Section I), either NW must also decline or TA must rise, or both. If the more standard assumption of a stable ratio of net worth to income is approximately correct, then under this alternative view the counterpart to the relative decline in government liabilities documented in Table 1 and Figure 1 would have been a relative rise in the private sector's holdings of tangible assets - presumably including not only corporate assets 
in the form of productive plant and equipment but also private holdings of residential real estate and consumer durables. Moreover, it is clear from (14) that, if TA rises while NW remains unchanged, then either FA must decline or $\mathrm{L}^{\mathrm{P}}$ must also rise.

The potential importance of credit market constraints under this view is most readily apparent in the household sector's debt arrangements. In fact, borrowing against tangible assets in the form of home mortgage and consumer installment credit has constituted the overwhelming majority of the household sector's credit market indebtedness at least since World War II (89\% as of yearend 1978). Similarly, the borrowing of many corporations consists primarily of explicitly secured long-term market debt, in the form of mortgages or "first mortgage" bonds, and implicitly secured short-term bank debt matched by inventory holdings.

Under the "capital leveraging" hypothesis to explain the stability of the total nonfinancial debt ratio, credit market constraints effectively prohibit the private sector from freely substituting its own liabilities in place of the government's declining liabilities. Instead, the private sector can increase its own liabilities only to the extent that it is also accumulating more tangible assets with which to back them. The stability of the U.S. nonfinancial debt ratio therefore reflects in the first instance an increase in tangible assets in approximately the proportion necessary to hold net worth fixed in relation to income as ownership of government liabilities declines relative to income. By shifting outward the effective credit market constraints, this relative increase in tangible assets then facilitates the increase in private financial liabilities. From (14) once again, if private liabilities increase fully in step with tangible asset holdings, then not only net worth but also private financial asset holdings will remain stable 
in relation to income.

This capital leveraging hypothesis also bears a number of interesting implications that extend beyond questions of portfolio behavior and the importance of borrowing constraints per se. Like the "ultrarationality" hypothesis, for example, it implies that the government deficit is a major determinant of the economy's physical investment. Unlike that hypothesis, however, it does not require that consumption move to offset tax payments. Hence fiscal policy can affect not just the composition of income but also its total.

An Asset Demand Hypothesis. Finally, a third approach to explaining the debt stability phenomenon combines some elements of both of the two hypotheses developed above.

According to the ultrarationality hypothesis, the private sector not only acts so as to maintain a stable ratio of net worth to income but also maintains separately stable ratios for both total assets and total liabilities. A variant of that hypothesis would be to assume in addition the existence of behavior enforcing stable ratios to income not just for total assets but, in addition, for the specific components of that asset total - tangible and financial. In other words, the streams of services yielded by tangible and financial assets are sufficiently weak substitutes that individual maximizers exhibit stable demands for each separately in proportion to income. If people seek to maintain a stable relationship between financial asset holdings and income, then the market-clearing constraint (15) immediately indicates that any relative decline in the given supply of the government's liabilities will be matched by an increase in the demand for private liabilities. If this demand is insensitive to such factors as yield (which is what a stable ratio implies in this context), then a yield-sensitive supply of private 
liabilities will adjust so as to clear the market for financial claims at a quantity that represents a stable ratio to income for total financial assets held, and a ratio for private liabilities owed that rises so as to offset the decline in government liabilities.

An alternative route to the same result is to combine with the capital leveraging hypothesis the assumption of a stable demand for financial assets. As the discussion above has already noted, it is clear from (14) that, if NW is stable and TA rising (to offset the decline in $L^{G}$ ), then either FA must decline or $\mathrm{L}^{\mathrm{P}}$ must rise (or both). If, in addition, the demand for financial assets bears a stable relation to income, then necessarily private liabilities will rise.

In either case - that is, under ultrarationality with a stable ratio of tangible assets to income, or under capital leveraging with a rising tangible asset ratio - the distinguishing characteristic of the "asset demand" hypothesis is the assumption of a stable, interest insensitive demand for financial assets in relation to income. The supply of private liabilities then adjusts, either just to clear the financial claims market or, alternatively, to facilitate the holding of more tangible assets while holding no less financial assets. Either way, a decline in government liabilities leads to a rise in private liabilities. 
III. Some Evidence from Household and Corporate Sector Balance Sheets

The U.S. Aggregate Net Balance Sheet. As of yearend 1978 the consolidated balance sheet of the private domestic U.S. economy showed a combined net worth of $\$ 7.3$ trillion, consisting of $\$ 5.1$ trillion of reproducible tangible assets (valued at reproduction cost), ${ }^{19} \$ 1.5$ trillion of land (at market value), $\$ 535$ billion of net claims against the federal government (excluding Social Security claims), \$100 billion of net claims against state and local governments, and $\$ 106$ billion of SDRs, gold (valued at the official price) and net claims against foreigners. The largest two holders of these assets were households $(\$ 3.8$ trillion, net of pension reserves and equity claims on corporations and unincorporated businesses) and nonfinancial nonfarm corporations ( $\$ 1.6$ trillion). 20

In order to avoid missing phenomena that may be lost in aggregation, in examining the data to look for patterns that may shed light one way or the other on the hypotheses outlined in Section II it is useful to focus at first on the holdings of specific sectors rather than on fully consolidated totals. Since households and nonfinancial corporations not only hold the great majority of the economy's net worth but also account for most of the nonfederal liabilities shown in Table 1 and Figure 1 , the object of this section is to seek some perspective on the alternative hypotheses suggested in Section II by examining movements in the balance sheets of these two sectors during the post World War II period.

Households. Figure 3 plots the four chief components of the household sector's balance sheet (with equity claims and pension reserves not netted out) grouped as in (14), measured again as ratios of yearend stocks to seasonally adjusted fourth-quarter gross national product. On balance the 

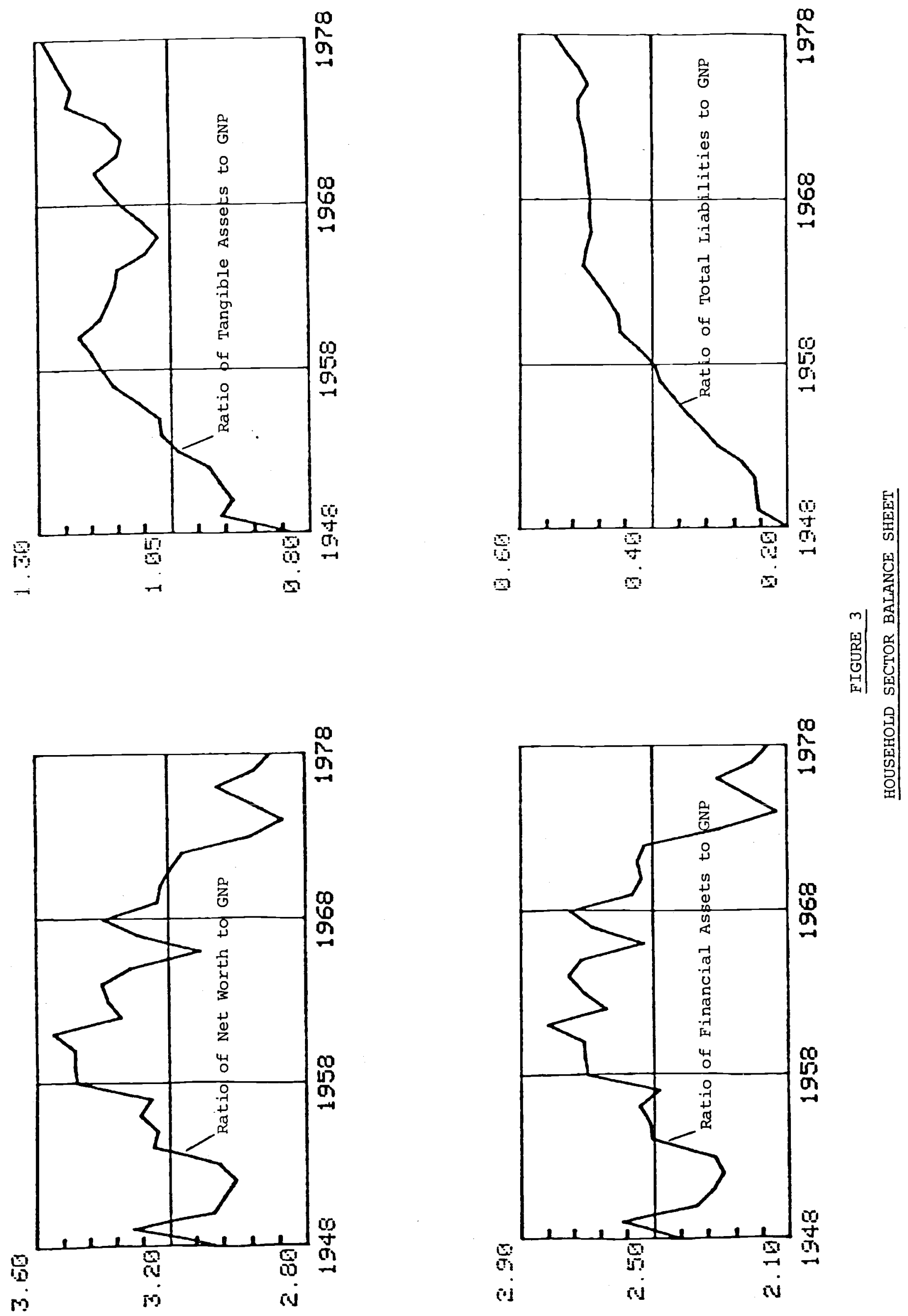
net worth ratio - assumed to be steady in all three of the hypotheses advanced in Section II - exhibited substantial variation but little overall trend through the early 1970s, first rising in the 1950 s and then declining in the 1960s. The continuation of the decline into the 1970s, however, has resulted in a slight downward trend for the postwar period as a whole. Within the net worth total, tangible asset holdings have risen irregularly throughout this period, while the much larger financial asset holdings (dominated by equity. claims) have shown the rising and then falling pattern also exhibited by net worth. As is already familiar from Table 1 and Figure 1 , households' liabilities have risen throughout, although the pace of the increase was significantly slower during 1964-75 than either before or since. ${ }^{21}$ Although the large variation in the value of households' financial asset holdings due to equity price movements makes it difficult to generalize from these data, it does not appear that households have held their balance sheet proportions fixed - as the asset demand hypothesis put forth in Section II would imply - over this period. This variation is even more apparent in Figure 4, which shows the almost continuously rising ratio of households' total assets (tangible plus financial) to their net worth. Moreover, Figure 5 shows that the ratio of households' liabilities to their tangible assets which the capital leveraging hypothesis put forth in Section II suggests should be stable - also rose steadily until the early 1960s, although on balance it has displayed little trend movement subsequently. 'Finally, Figure 6 plots net worth and financial asset ratios for the household sector that are analogous to those in Figure 3 but with equity claims and pension reserves subtracted out. Here it is clear that, apart from changes in equity holdings and pension reserves, the 1965-78 decline in financial asset holdings relative to gross national product has been insufficient to offset the 1953-64 


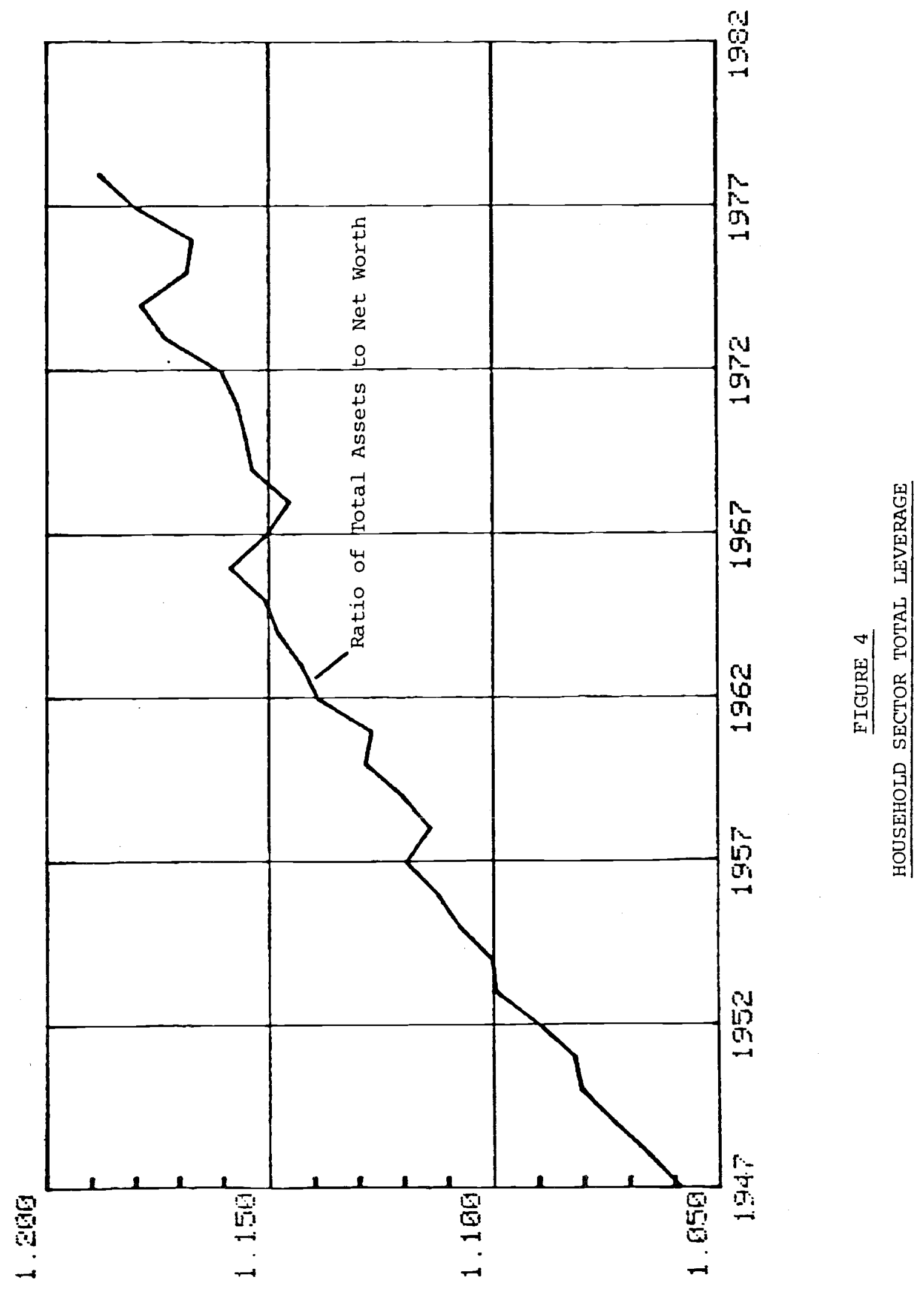




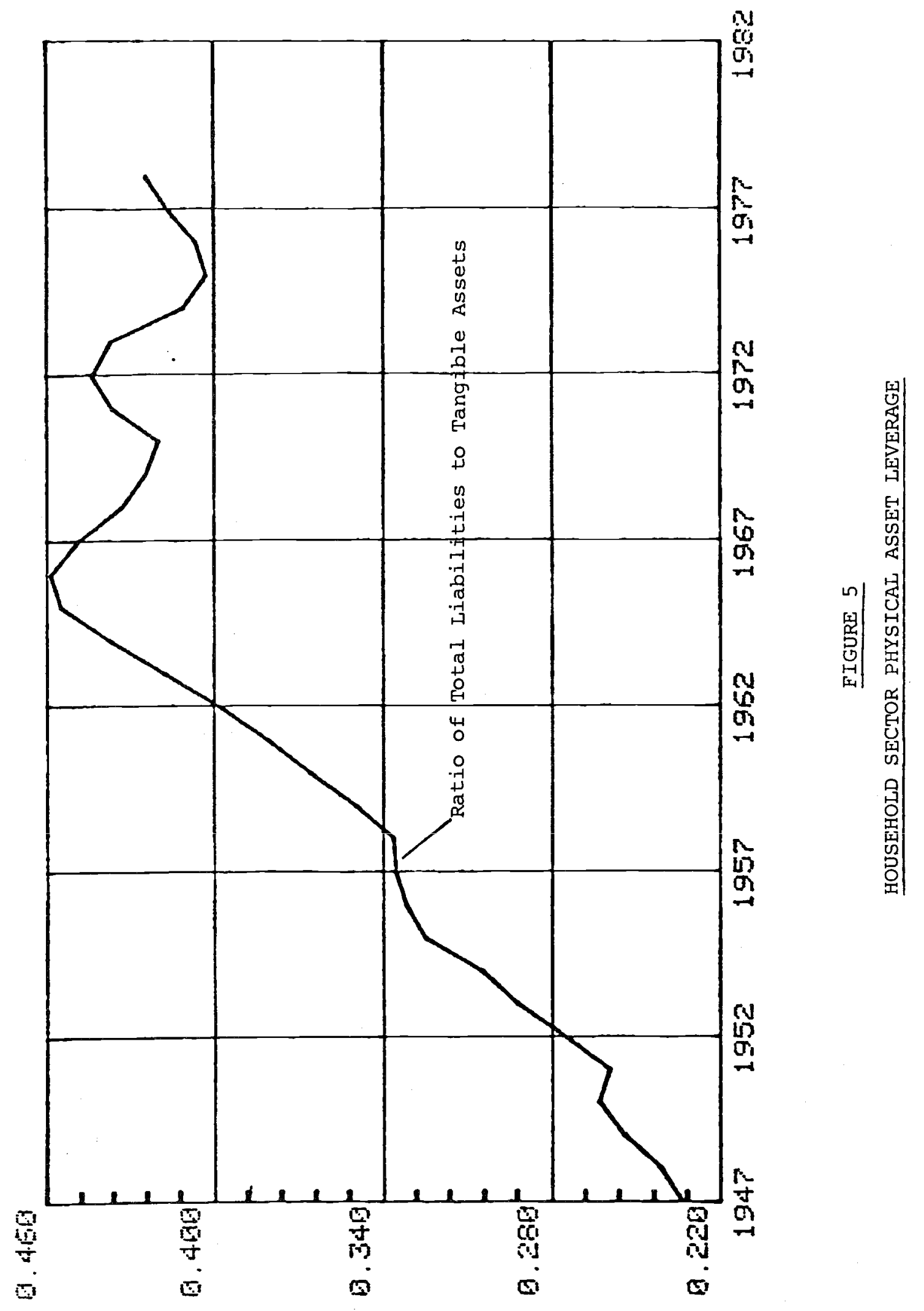


1.85

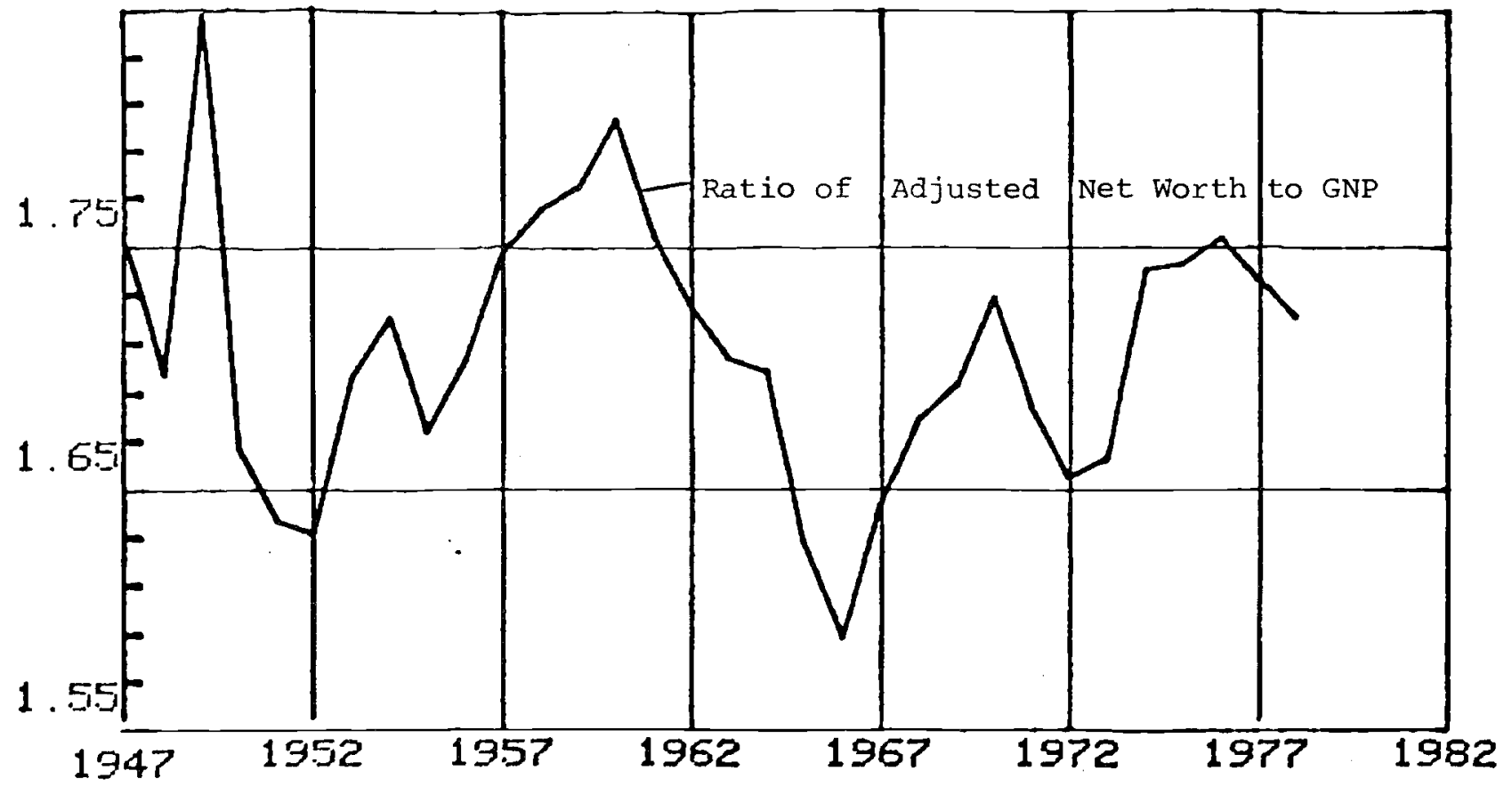

1. 100

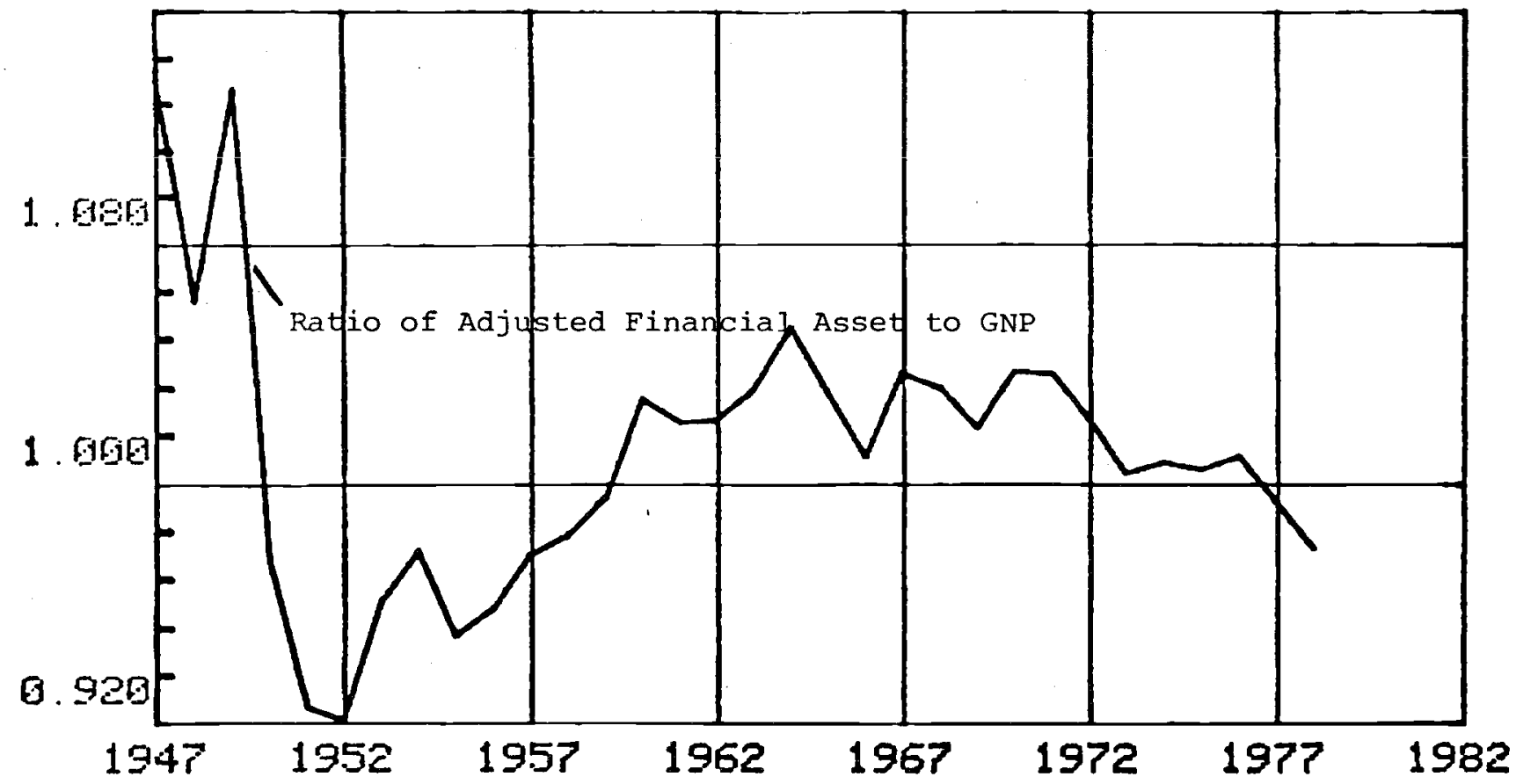

FIGURE 6 
rise. Hence on this netted basis households have actually been increasing their financial asset holdings just as they have been increasing their tangible asset holdings, so that the ratio of their net worth to gross national product has on balance shown a very slight increase over the entire 1953-78 period - in contrast to the decline shown in Figure 3. Simple inspection of these data for households alone yields conclusions that are, on the whole, unsympathetic to all three hypotheses suggested in Section II. Household net worth, including equity claims valued at market, has not been steady but has declined in relation to income; netting out claims against the government, as under the ultrarationality hypothesis, would only make it show an even greater decline. Similarly, although household net worth with equity claims subtracted out has shown a very slight upward trend, netting out claims against the government would still change that to a pronounced downward trend. In addition, households have not increased their outstanding indebtedness only in pace with their tangible asset holdings, as would be the case under the capital leveraging hypothesis. Instead, households have steadily borrowed more against these assets, thereby substantially increasing their overall leverage. Finally, the ratio of financial assets to income has not remained fixed either, as would be the case under the asset demand hypothesis.

Nevertheless, a more careful examination of these data using vector autoregression methods does suggest a response of households' liability behavior to government borrowing, as is consistent with all three hypotheses from Section II, as well as at least some response of households' tangible asset holdings as would be implied by the capital leveraging hypothesis. Table 9 presents simulation results for a three-variable vector autoregression system including the ratios to gross national product of federal government 
TABLE 9

DYNAMIC RESPONSES OF HOUSEHOLD SECTOR LIABILITIES AND TANGIBLE ASSETS

Ratio to Nominal Income of:

\begin{tabular}{ccc} 
& Ratio to & Nominal Income of: \\
Net & Household & Net \\
Federal & Tangible & Household \\
Liabilities & Assets & Liabilities \\
\hline
\end{tabular}

Response to 18 Impulse Innovation in Net Federal Liabilities Ratio:

Year

1

2

3

4

5

6

7

8

9

10
$1.00 \%$

.66

.42

.19

.03

$-.07$

$-.11$

$-.09$

$-.01$

.09
$0.00 \%$

0.008

$-.78$

.05

$-1.09$

.06

$-1.23$

$-.02$

$-.13$

$-1.16$

$-.91$

$-.24$

$-.54$

$-.33$

$-.37$

$-.11$

.28

$-.37$

.60

$-.32$ 
liabilities, household tangible assets $\left(\mathrm{TA}^{\mathrm{H}}\right)$ and housebold liabilities $\left(\mathrm{L}^{\mathrm{H}}\right.$ ), estimated using annual data and solved analogously to (10) and (11) for the vector $\left[\ln \left(L^{G} / Y\right) t_{t^{\prime}} \ln \left(\mathrm{TA}^{\mathrm{H}} / \mathrm{Y}\right) t_{t^{\prime}} \ln \left(\mathrm{L}^{\mathrm{H}} / \mathrm{Y}\right)_{t}\right]^{\prime}$, and orthogonalized to extract the independent innovation in $L^{G} / Y$. Beginning in the second year, the household tangible assets ratio declines sharply in response to an innovation in the government debt ratio. In addition, after a somewhat puzzling delay of four years, the household debt ratio declines as well. While the tangible assets ratio eventually returns to (actually above, though not significantly so) its original value, as is consistent with proportional demands for the stream of housing and other durable goods services in relation to income, the debt ratio remains depressed through the tenth year. Although the specific magnitudes and time patterns of these responses clearly require further explanation, and further investigation using the underlying variables rather than just ratios is necessary to distinguish portfolio responses from income responses, these results do suggest at least some role for households' behavior in accounting for the observed stability of the U.S. aggregate nonfinancial debt ratio in ways consistent with the ideas advanced in section II. Nonfinancial Corporations. Figure 7 plots ratios for the same four components shown in Figure 3, from the aggregate balance sheet of nonfarm nonfinancial business corporations. These data appear, if anything, even more puzzling from the perspective of the hypotheses advanced in section II. The ratio of corporate net worth to income has moved more in step with than against the household net worth ratio, so that there has been no observable tendency for variations of the two to offset one another as the ultrarationality hypothesis might suggest. Corporate tangible asset holdings relative to gross national product have shown an upward trend overall, as would be the case under the capital leveraging hypothesis, but with a steep decline 

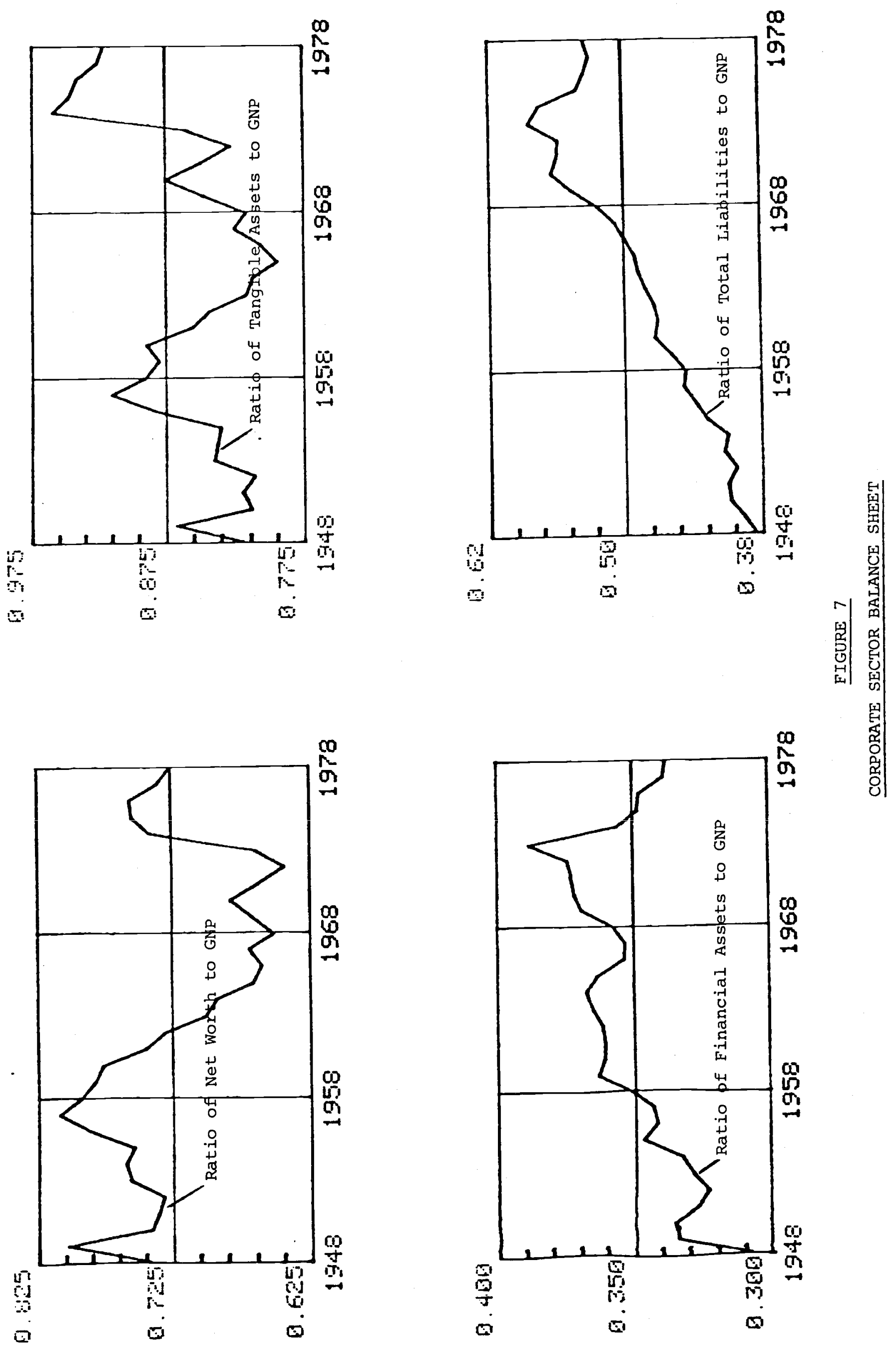
in the late 1950 s and early 1960 s. $^{22}$ Corporate financial asset holdings relative to gross national product rose irregularly through 1973 and have subsequently declined, rather than remaining steady as the asset demand hypothesis would require. Finally, corporate liabilities have followed much the same pattern as corporate financial assets, although with more amplitude and somewhat more smoothness. 23 As Figures 8 and 9 show, corporations have, like households, increased their overall leverage either by borrowing more against their physical assets or by borrowing against their holdings of financial as well as physical assets.

Once again, however, closer inspection of these data using vector autoregression methods suggests conclusions more sympathetic to the hypotheses in Section II, and in particular to the capital leveraging hypothesis. Table 10 presents simulation results analogous to those in Table 9, for a threevariable vector autoregression system including the ratios to gross national product of federal government liabilities, corporate tangible assets (TA $\mathrm{C}$ ) and corporate liabilities $\left({ }^{C}\right)$, estimated using annual data and solved analogously to (10) and (11) for the vector $\left[\ln \left(L^{G} / Y\right) t_{t^{\prime}} \ln \left(T A^{C} / Y\right) t_{t^{\prime}} \ln \left(L^{C} / Y\right)_{t}\right]^{\prime}$, and orthogonalized to extract the independent innovation in $L^{G} / Y$. Here the innovation in the government debt ratio immediately results in a large decline in the corporate tangible assets ratio as well as the corporate debt ratio. The effect of the original innovation on all three variables in the system essentially disappears by the fourth year. Even more so than the results for the household sector shown in Table 9, these response patterns appear approximately consistent with what the hypotheses of section II - and especially the capital leveraging hypothesis - would lead one to expect. 


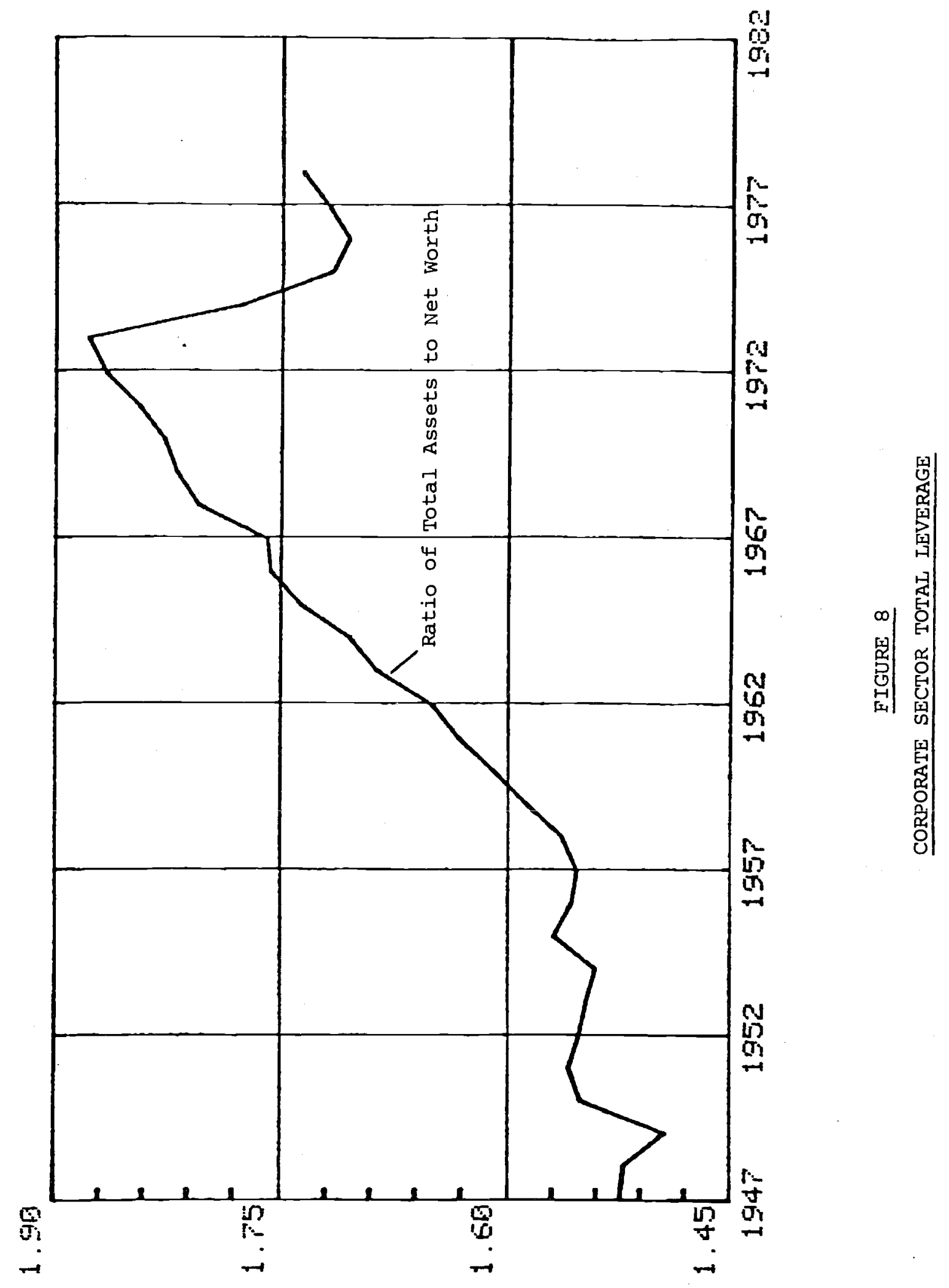




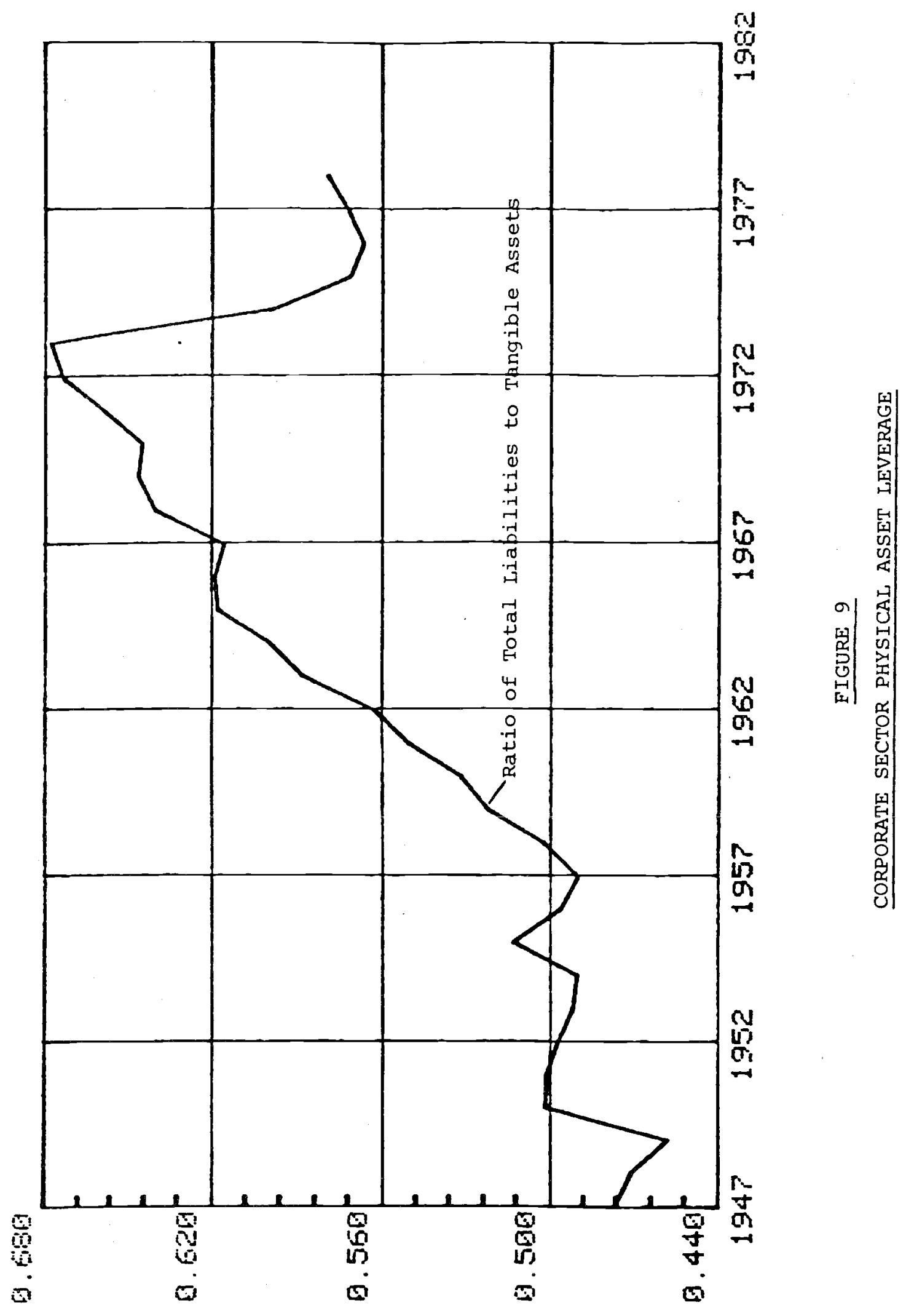


TABLE 10

DYNAMIC RESPONSES OF CORPORATE SECTOR LIABILITIES AND TANGIBLE ASSETS

\begin{tabular}{ccc}
\multicolumn{2}{c}{ Ratio to Nominal Income of: } \\
Net & Corporate & Net \\
Federal & Tangible & Corporate \\
Liabilities & Assets & Liabilities \\
\hline
\end{tabular}

Response to 18 Impulse Innovation in Net Federal Liabilities Ratio:

Year

1

2

3

4

5

6

7

8

9

10
1.008

.75

.13

$-.05$

.08

.24

.30

.25

.17

.09
0.008

$-1.40$

$-.83$

.10

.42

.26

$-.03$

$-.22$

$-.25$

$-.18$
$0.00 \%$

$-.44$

$-.30$

$-.10$

$-.05$

$-.09$

$-.13$

$-.14$

$-.12$

$-.09$ 


\section{Concluding Comments}

The analysis in this paper suggests several conclusions.

First, results based on a variety of methodological approaches ranging from simple inspection of ratios, to nominal income regressions, to bivariate and more complex vector autoregression systems - consistently indicate that the aggregate debt of all nonfinancial borrowers in the United States bears as close a relationship to U.S. nonfinancial economic activity as do the more familiar asset aggregates like the money stock (however measured) or the monetary base. In contrast to the asset aggregates, however, which exhibit little overall difference among themselves in this context, total nonfinancial indebtedness appears to be unique among liability aggregates in the stability of this relationship. Moreover, the data show evidence of a negative covariance between the public and private components of total nonfinancial indebtedness, thereby further substantiating the case for stability in the aggregate.

Second, three hypotheses (that is, at least three) provide internally consistent potential explanations for this phenomenon: an "ultrarationality" hypothesis which emphasizes acute perceptions and offsetting actions on the part of the private sector, a "capital leveraging" hypothesis which emphasizes credit market constraints, and an "asset demand" hypothesis which emphasizes market clearing and the private sector's role as a net lender.

Third, initial efforts to match these three hypotheses against the data for the household and corporate business sectors yield mixed results. Simple inspection of the data leads to impressions largely inconsistent with any of the three, but the results of vector autoregression experiments are more supportive, especially of the "capital leveraging" hypothesis. 
It is important to re-emphasize, however, that - as was noted at the outset - these simple experiments stop well short of rigorously formulating and testing any of the three hypotheses at hand. One immediate reason for caution, of course, is merely the usual important distinction between descriptive statistics and test statistics, but other problems are present too. Although the basic phenomenon documented in the first part of this paper concerns the joint behavior of all nonfinancial borrowers in the economy, the "tests". assembled in the latter part focus separately on household and corporate behavior patterns. The relevant concept of nonfinancial economic activity for this purpose is problematical as well. Nominal gross national product is not necessarily the best measure even for aggregate-level investigations, despite its conventional acceptance in analogous contexts, and it is even more questionable for issues focused specifically on household or corporate sector activity. Allowing in some way a role for equity claims, along with the debt claims, would broaden but no doubt also further complicate the analysis.

Nevertheless, even on the basis of the results reported in this paper, the case for some redirection of "monetary" economics research toward the nonbank public's liabilities as well as its assets appears warranted. 


\section{Appendix}

The othogonalization procedure outlined in $(3)-(6)$ in section I constructs the independent innovation $\varepsilon_{1}$ as that part of the underlying vector autoregression disturbance $\mu_{1}$ which excludes all contemporaneous covariation between $\mu_{1}$ and $\mu_{2}$, and constructs the analogous independent innovation $\varepsilon_{2}$ as that part of $\mu_{2}$ which excludes any contemporaneous covariation between $\mu_{1}$ and $\mu_{2}$. This concept of what constitutes an "independent innovation" is equivalent to ranking. the variable in question last in a chain of causal ordering. By contrast, the terminology employed by Sims [15] defines an independent innovation $\varepsilon_{i}$ in such a system to include all contemporaneous covariation among the underlying $\mu_{i}$ and any $\mu_{j}, j \neq i$; this concept is equivalent to ranking the $i-t h$ variable first. Presumably some but not all of the variation common to all variables actually is specific to the one in question, so that the "truth" lies somewhere between these two extremes. Tests indicate that the choice of ordering for purposes of the orthogonalization - that is, the choice of whether to include or exclude contemporaneous covariation with other variables - makes no substantive difference in the simulation results shown in Tables 3 and 6-10 above. For each of the ten bivariate systems examined in Table 6, for example, Table A-1 shows the respective variances, covariance and correlation of the underlying $\mu_{1}$ and $\mu_{2}$ disturbances, and Table A-2 shows simulation results analogous to those in Table 6 except that here the system is orthogonalized so that the innovation labeled "independent" includes all of the contemporaneous $\left(\mu_{1}, \mu_{2}\right)$ covariation. Although some of the correlations shown in Table A-l are hardly small, the simulation results in Table $A-2$ are essentially unchanged from those in Table 6. 


$\underline{\operatorname{var}\left(\mu_{1}\right)} \quad \underline{\operatorname{var}\left(\mu_{2}\right) \quad\left(\mu_{1}, \mu_{2}\right)}$ correlation

\section{Assets}

Monetary Base
Money (M1)
Money (M2)
Money (M3)
Net Financial Assets

Liabilities

Total Net Liabilities

Total Liabilities

Net Non-federal Liabilities

Net Private Liabilities

Bank Credit

$\begin{array}{rrrr}.1008 & .6261 & .0018 & .01 \\ .1484 & .6500 & .0919 & .30 \\ .1881 & .5406 & .0545 & .17 \\ .1245 & .2982 & .0142 & .07 \\ .1048 & .5848 & .0866 & .35\end{array}$

$\begin{array}{llll}.0702 & .6569 & .0676 & .32 \\ .0990 & .6958 & .0975 & .37 \\ .4485 & .6869 & .0805 & .46 \\ .0551 & .6726 & .0912 & .47 \\ .7788 & .6503 & .0859 & .12\end{array}$

Notes: $\mu_{1}$ is the disturbance in the equation with the asset or liability total as dependent variable.

$\mu_{2}$ is the disturbance in the equation with nominal income as dependent variable.

Sample period is 1953-1978 (1959-78 for M3). 


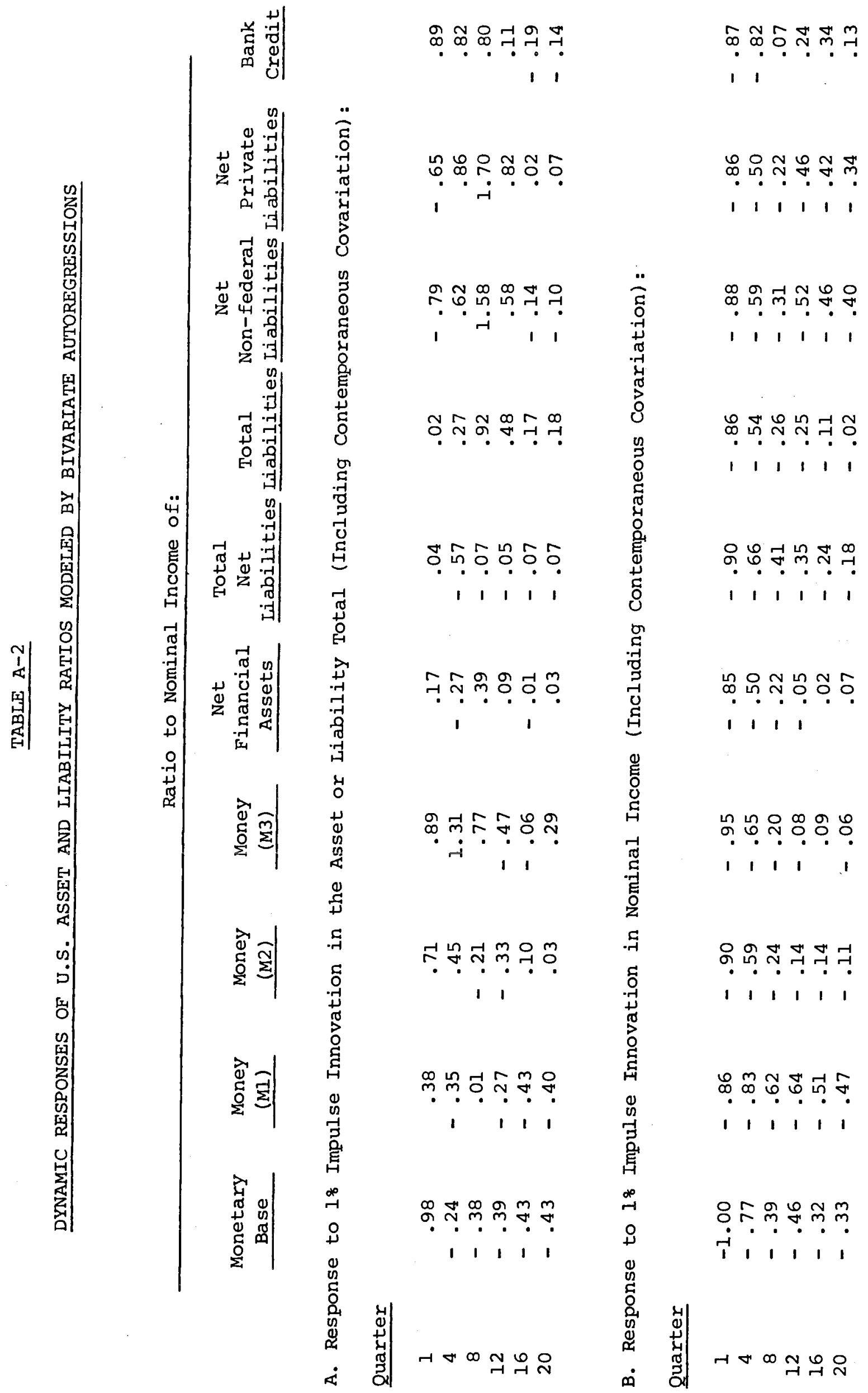


Footnotes

* This paper is a part of the National Bureau of Economic Research project on "The Changing Roles of Debt and Equity in Financing U.S. Capital Formation", sponsored by the American Council of Life Insurance. I am grateful to Angelo Melino and Chris Piros for research assistance; to them as well as Richard Davis, James Duesenberry, Michael Hamburger, John Scadding, Christopher sims and stephen Taylor for helpful discussions; and to the National Bureau and the Alfred P. Sloan Foundation for research support.

1. Among models familiar in the current literature, that of Brunner and Meltzer [1] - in which money and credit are both determined as the product of their respective endogenous "multipliers" and the exogenous monetary base - probably comes closest to representing this view. Even so, Brunner and Meltzer have stopped well short of denying any significance to the money and credit totals thus determined.

2. In part because of the capital export controls that were in force during 1964-74, foreign obligors accounted for only a small fraction of borrowing in the U.S. markets throughout this period.

3. See Friedman [8] for a discussion of the postwar versus prewar periods. Figure 2 below is from [8].

4. The debt ratio peak during 1918-78 occurred in 1933, the trough year of the depression. In addition, much of the household and business debt nominally outstanding during the depression was of questionable value.

5. The difference between the two is small, consisting for the most part of bonds issued by finance companies and federally sponsored credit agencies and mortgage pools. Most liabilities of financial intermediaries (for example, deposits and life insurance and pension reserves) are not classified as credit market liabilities in the Federal Reserve's flowof-funds accounts.

6. Because these four series are measured weekly or monthly, rather than at the end of each quarter, it is necessary to determine how to construct the ratios. The quarterly data use quarterly averages in the numerator. The annual data use December averages in the numerator because this method made the respective coefficients of variation smaller in every case except the detrended M2 ratio; in that one case the value computed using the quarterly average in the numerator is .027 .

7. See sims [15] for a discussion of the methodology and rationale underlying the vector autoregression approach.

8. The effect of the shortened sample period for $M 3$ is immediately apparent from the contrast between the small standard error and the large (but not all that large) $\overline{\mathrm{R}}^{2}$. 
9. For leading examples of this evidence, see De Rosa and Stern [3], Diggins [5], Feige and McGee [6], and Lombra and Moran [11].

10. Lindsey [10] has argued along these lines for the case of bank credit.

11. See, for example, Goldfeld and Blinder [9], Sargent [14], and Modigliani and Ando [13].

12. The use of levels of logarithms in (8) instead of differences of logarithms as in (7) has essentially no effect as long as the lag lengths of the $B_{i j}$ are sufficient to provide roots near the unit circle. (If no roots near the unit circle are needed, then the differencing in (7) is incorrect in the first place.)

13. See, for example, Tobin and Buiter [16].

14. See, for example, Modigliani [12].

15. Some analyses distinguish between outside money and government debt, so that (15) need not hold if the outside money is excluded from $L G$. The data for $L^{G}$ used in this paper exclude currency but include the Federal Reserve System's holdings of other government debt, so that only the difference between the two would be at issue here. As of yearend 1978 currency outside banks was $\$ 99.1$ billion and member banks' reserves were $\$ 46.7$ billion, against $\$ 118.6$ billion of Federal Reserve holdings of U.S. Government securities.

16. Just as (14) ignores the government's holdings of financial assets, (16) ignores the equity (capital) position of intermediaries.

17. See Friedman [7] for an analysis distinguishing intermediate target variables and information variables.

18. Alternatively, one could express the same concept as a stable ratio of net worth to income plus a stable leverage ratio - defined, for example, as the ratio of total assets to net worth.

19. The composition of the tangible assets included \$1.9 trillion of residential structures, $\$ 1.8$ trillion of nonresidential plant and equipment, $\$ 793$ billion of business inventories, and $\$ 574$ billion of consumer durables.

20. The other holdings by sector were $\$ 805$ billion for unincorporated nonfarm businesses, $\$ 629$ billion for farms, and $\$ 490$ billion for private financial institutions (net of corporate equity claims, but including pension reserves credited to households). These figures, as well as the sector detail used throughout this section, are from unpublished Federal Reserve Board data. 
21. In contrast to the data in Table 1 and Figure 1 , which include only credit market liabilities, the data shown here include all liabilities. Most household liabilities are in fact credit market liabilities; the difference, consisting of security credit, trade credit, and deferred or unpaid life insurance premiums, was less than $4 \%$ of total liabilities as of yearend 1978 .

22. It would be useful in future research to divide the sharp post-1972 rise into quantity versus relative price components.

23. The liabilities data in Figure 7 also differ from those in Figure 1 and Table 1 by including all liabilities. (See again footnote 21.) of the \$1.179 trillion of non farm nonfinancial corporations' liabilities outstanding as of yearend 1978, only $\$ 835$ billion (just over 70\%) were credit market liabilities; the remainder included $\$ 282$ billion of trade debt, $\$ 22$ billion of unpaid profit taxes, and $\$ 39$ billion of other miscellaneous liabilities. 


\section{References}

1. Brunner, Karl, and Meltzer, Allan H. "Money, Debt and Economic Activity." Journal of Political Economy, LXXX (September/October, 1972), 951-977.

2. David, Paul A., and Scadding, John L. "Private Savings: Ultrarationality, Aggregation, and 'Denison's Law'." Journal of Political Economy, LXXXII (March/April, 1974), 225-249.

3. De Rosa, Paul, and Stern, Gary. "Monetary Control and the Federal Funds Rate." Journal of Monetary Economics, III (April, 1977), 217-230.

4. Denison, Edward F. "A Note on Private Saving." Review of Economics and Statistics, XL (August, 1958), 261-267.

5. Diggins, James R. A Short Term Model of Federal Reserve Behavior in the 1970's. Unpublished Ph.D. dissertation, Harvard University, 1978.

6. Feige, Edgar L., and McGee, Robert. "Has the Federal Reserve Shifted from a Policy of Interest Rate Targets to a Policy of Monetary Aggregate Targets?" Journal of Money, Credit and Banking, XI (November, 1979), $381-404$.

7. Friedman, Benjamin M. "Targets, Instruments and Indicators of Monetary Policy." Journal of Monetary Economics, I (October, 1975), 443-473.

8. Friedman, Benjamin M. "Postwar Changes in the American Financial Markets." Martin S. Feldstein (ed.), The American Economy in Transition. Chicago: University of Chicago Press, forthcoming.

9. Goldfeld, Stephen M., and Blinder, Alan S. "Some Implications of Endogenous Stabilization Policy." Brookings Papers on Economic Activity (No. 3, 1972), 585-640.

10. Lindsey, David E. "The Relationship of GNP to Various Money and Credit Aggregates." Mimeo, Board of Governors of the Federal Reserve System, 1976.

11. Lombra, Raymond, and Moran, Michael. "Policy Advice and Policymaking at the Federal Reserve." Journal of Monetary Economics (Supplement), forthcoming.

12. Modigliani, Franco. "The Life Cycle Hypothesis of Saving, the Demand for Wealth and the Supply of Capital." Social Research, XXX (Summer, 1966), $160-217$. 
13. Modigliani, Franco, and Ando, Albert. "Impacts of Fiscal Actions on Aggregate Income and the Monetarist Controversy: Theory and Evidence." Jerome Stein (ed.), Monetarism. Amsterdam: North-Holland Publishing Company, 1976.

14. Sargent, Thomas J. "The Observational Equivalence of Natural and Unnatural Rate Theories of Macroeconomics." Journal of Political Economy, LXXXIV (June, 1976), 631-640.

15. Sims, Christopher A. "Macroeconomics and Reality." Econometrica, XLVIII (January, 1980), 1-48.

16. Tobin, James, and Buiter, Willem. "Long-Run Effects of Fiscal and Monetary Policy on Aggregate Demand." Jerome Stein (ed.), Monetarism. Amsterdam: North-Holland Publishing Company, 1976. 